\title{
Chemical Constituents of Habenaria petalodes Lindl. (Orchidaceae)
}

\author{
Betania B. Cota, ${ }^{a}$ Alviclér Magalhães, ${ }^{b, \#}$ Adriano M. C. Pimenta, ${ }^{c}$ Ezequias P. Siqueira, ${ }^{a}$ \\ Tânia M. A. Alves ${ }^{a}$ and Carlos L. Zani* ${ }^{*}$ a \\ ${ }^{a}$ Laboratório de Química de Produtos Naturais, Av. Augusto de Lima, 1715, \\ 30190-002 Belo Horizonte-MG, Brazil
}

${ }^{b}$ Instituto Tecnológico de Fármacos, Rua Sizenando Nabuco, 100, 21041-250 Rio de Janeiro-RJ, Brazil

${ }^{c}$ Departamento de Bioquímica e Imunologia, Av. Antônio Carlos, 6.627, 31270-901 Belo Horizonte-MG, Brazil

\begin{abstract}
Uma nova substância, denominada habenariosídeo \{[(2R)-2-[(2,3,4,6-tetra- $O$-acetil- $\beta$-Dglicopiranosil)oxi]-2-(2-metilpropil)-1,4-dioxo-1,4-butanodiil]bis(oximetileno-4,1-fenileno) bis- $\beta$-D-glicopiranosídeo \}, foi isolada das frações polares do extrato etanólico de Habenaria petalodes Lindl. (Orchidaceae), juntamente com duas substâncias conhecidas e estruturalmente relacionadas, a loroglossina e a militarina. Os flavonóides: isoquercitrina, isorramnetina 3-O- $\beta$ D-glicopiranosídeo e isorramnetina 3,7-di-O- $\beta$-D-glicopiranosídeo, também foram isolados. As estruturas do habenariosídeo e das demais substâncias foram determinadas pela análise dos dados de EM, IV, UV e RMN mono e bidimensional e comparação com os dados publicados na literatura.
\end{abstract}

Habenarioside, a new natural product identified as $[(2 R)-2-[(2,3,4,6$-tetra- $O$-acetyl- $\beta$-Dglucopyranosyl)oxy]-2-(2-methylpropyl)-1,4-dioxo-1,4-butanediyl]bis(oxymethylene-4,1phenylene) bis- $\beta$-D-glucopyranoside, along with two known related metabolites, loroglossin and militarin, were isolated from the ethanol extract of the whole plant Habenaria petalodes Lindl. (Orchidaceae). The flavonoids isoquercitrin, isorhamnetin 3-O- $\beta$-D-glucopyranoside, and isorhamnetin 3,7-di- $O$ - $\beta$-D-glucopyranoside were also isolated. The structures of all compounds were established by analysis of their MS, IR, UV, 1D and 2D NMR spectra, and comparison with published data.

Keywords: orchid, loroglossin, militarin, habenarioside, flavonoids

\section{Introduction}

The Brazilian flora is exceedingly rich and comprises more than 56,000 endemic plant species. Among the 22,000 members of the family Orchidaceae that have been described worldwide, approximately 1,800 grow endemically in Brazil. ${ }^{1}$ In spite of its size and diversity when compared with other plant families, a relatively small number of orchid species have been investigated regarding their chemical composition, with about 300 secondary metabolites reported so far. These included, among others, flavonoids, terpenoids, quinones, phenanthrenes, stilbenes, lignans, and glucosylated benzyl

"Present address: Instituto de Física de São Carlos, Universidade de São Paulo, Av. do Trabalhador São Carlense, 400 13566-590 São Carlos-SP, Brazil

*e-mail: zani@cpqrr.fiocruz.br esters of succinic, malic, tartaric and citric acids..$^{2-6}$ The phytochemical investigations of Brazilian Orchidaceae are also restricted to few published works: a report concerning the presence of methylated C-glycosylflavones as taxonomic markers in fifteen orchids, ${ }^{7}$ and the investigation of the floral composition of other twenty-one species. ${ }^{8}$

The genus Habenaria (Orchidaceae) comprises over 600 species of which around 170 occur in Brazil. ${ }^{9}$ However, to the best of our knowledge only Habenaria repens Nutt. was chemically investigated so far, resulting in the identification of habenariol, a compound with potent feeding deterrent activity. ${ }^{10-12}$ In the present paper we report the first phytochemical investigation of Habenaria petalodes Lindl., describing the isolation and structure elucidation of six compounds (1-6), including a new 2-malic acid derivative (4) denominated habenarioside. 


\section{Results and Discussion}

The whole plant was extracted by maceration with ethanol and the extract was subjected to liquid-liquid partition between $\mathrm{CH}_{2} \mathrm{Cl}_{2}$ and $\mathrm{MeOH}: \mathrm{H}_{2} \mathrm{O}$ (1:1) to afford an organic and a hydroalcoholic fraction. The latter was subjected to solid phase extraction (SFE) using RP-18 cartridges followed by semi-preparative RP-HPLC to yield six compounds (Figure 1-2).

The ESI-MS of compounds $\mathbf{1}$ and $\mathbf{5}$ exhibited quasimolecular ion peaks $\left([\mathrm{M}+\mathrm{Na}]^{+}\right)$at $m / z 765$ and $m / z 749$, respectively. Their molecular weight, together with their $\mathrm{UV},{ }^{1} \mathrm{H}$ and ${ }^{13} \mathrm{C}$ NMR data were in accordance with those reported for loroglossin (1) and militarin (5). . $^{5,14}$

Habenarioside (4) was isolated as a resinous material with negative specific rotation $\left([\alpha]_{\mathrm{D}}{ }^{25}-30.0^{\circ}, c 0.16\right.$ in $\left.\mathrm{MeOH}\right)$. The positive HRESIMS spectrum showed a quasi-molecular ion peak $[\mathrm{M}+\mathrm{Na}]^{+}$at $\mathrm{m} / \mathrm{z}$ 1079.3578, consistent with the molecular formula $\mathrm{C}_{48} \mathrm{H}_{64} \mathrm{O}_{26}$ (calc. 1079.3584). The ESI-MS in positive ion mode showed neutral losses of $60 \mathrm{Da}$, attributed to the presence of acetate groups. Its IR spectrum exhibited absorption bands at $1755 \mathrm{~cm}^{-1}(\mathrm{C}=\mathrm{O}), 1612$ and $1512(\mathrm{C}=\mathrm{C}), 1234(\mathrm{C}-\mathrm{O})$ due to ester carbonyl functions and aromatic rings, and strong absorptions at $3433(\mathrm{OH})$ and

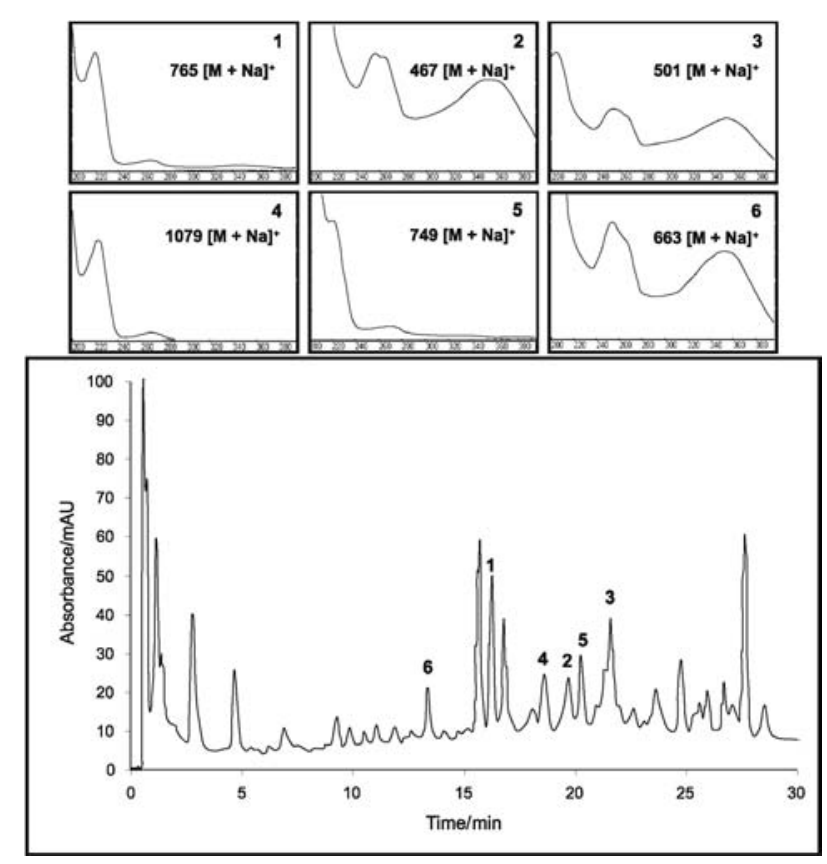

Figure 1. HPLC chromatogram of $H$. petalodes ethanol extract (UV detection at $230 \mathrm{~nm})$, and UV spectra $(200-400 \mathrm{~nm})$ of loroglossin (1), isoquercitrin (2), isorhamnetin 3-O- $\beta$-D-glucopyranoside (3), habenarioside (4), militarin (5), and isorhamnetin 3,7-di- $O-\beta-\mathrm{D}-$ glucopyranoside (6). Column, $250 \mathrm{~mm} \times 4.6 \mathrm{~mm}$ i.d.; mobile phase, $\mathrm{MeOH}: \mathrm{H}_{2} \mathrm{O}(10: 90 \rightarrow 70: 30$ in $30 \mathrm{~min} ; 70: 30 \rightarrow 100:$ in $5 \mathrm{~min})$, flow rate

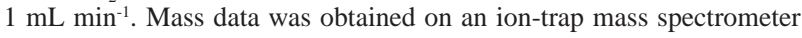
equipped with an ESI ion source operating in the positive ion mode.
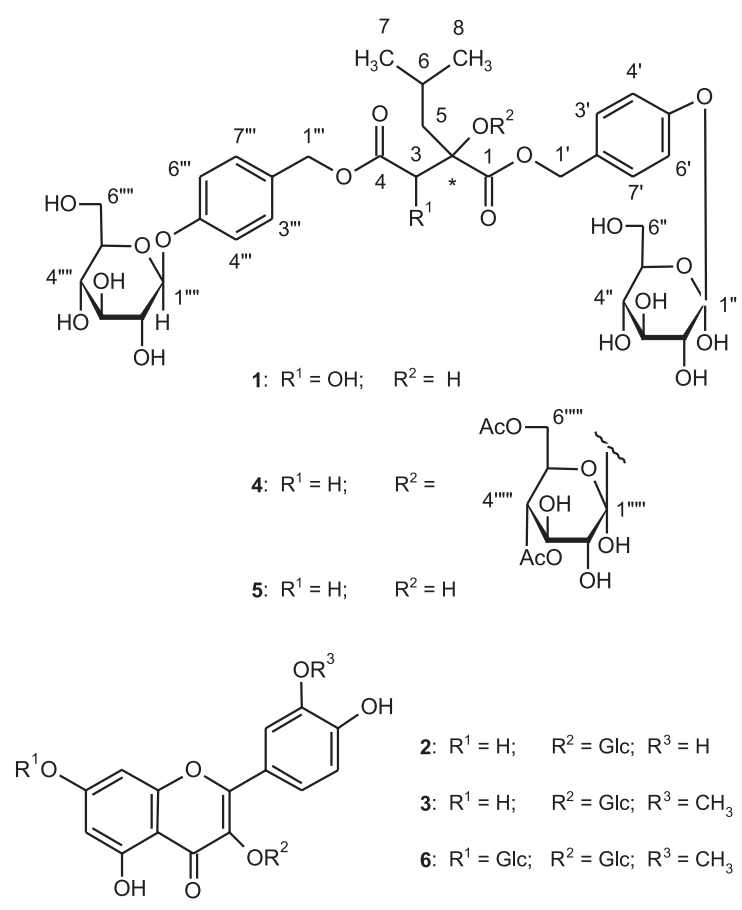

Figure 2. Structures of isolated compounds from Habenaria petalodes.

1072 (C-O) indicating the presence sugar moieties. Acid hydrolysis of $\mathbf{4}$ followed by reduction and acetylation, and GC-MS analysis of the resulting alditol acetate, confirmed the presence of D-glucose by comparison with an authentic sample. In the UV spectrum of $\mathbf{4}$, absorptions were similar to those of compounds $\mathbf{1}$ and $\mathbf{5}$ (Figure 1), with maxima observed at $224 \mathrm{~nm}(\log \varepsilon$ 3.76) and $271 \mathrm{~nm}$ (3.28). NMR spectra (Table 1) showed signals attributed to four acetyl groups at $\delta_{\mathrm{C}}(\mathrm{C}=\mathrm{O} / \mathrm{Me}) 171.6 / 20.9,171.8 / 20.7,171.5 / 20.9$, and $172.5 / 20.8$, and $\delta_{\mathrm{H}}(\mathrm{Me}) 1.95,1.97,2.01$, and 2.00. On the basis of DEPT spectrum other carbon resonances were ascribed to two methyls $\left(\delta_{\mathrm{C}} 23.6,25.0\right)$, four methylenes $\left(\delta_{\mathrm{C}} 44.8,50.2,67.6,68.1\right)$, a methine $\left(\delta_{\mathrm{C}} 24.9\right)$, seven quaternary carbons $\left(\delta_{\mathrm{C}} 81.7,130.8,131.1,2 \times 159.5\right.$, $172.1,173.3)$, and two sets of four aromatic carbons $\left(\delta_{\mathrm{C}}\right.$ $118.1,131.7$ and 118.0, 131.8). Also, signals due to the presence of three glucose units were evident in the HMQC experiment which showed correlations between pairs of anomeric protons and carbons with the following chemical shifts $\delta_{\mathrm{H}} / \delta_{\mathrm{C}}: 5.21 / 98.6,4.93 / 102.3$, and 4.89/102.5. The coupling constants between the anomeric protons and their respective $\mathrm{H}-2$ neighbor in the sugar moieties $\left({ }^{3} \mathrm{~J} 7.7 \mathrm{~Hz}\right)$ indicate that they are all in $\beta$ configuration. The above data appeared closely related to those of malic acid derivatives, gymnosides $(\mathrm{J} 7.6 \mathrm{~Hz})^{23}$ and dactylorhins $(J 7.5 \mathrm{~Hz})^{5}$. The HMBC experiments showed a clear correlation between the $\mathrm{C}-2\left(\delta_{\mathrm{C}} 81.7\right)$ in the malic acid skeleton and $\mathrm{H}-1$ "'," of a glucose moiety $\left(\delta_{\mathrm{H}} 5.21\right)$. The 
later form a complete hexose spin system, deducible from the ${ }^{1} \mathrm{H}-{ }^{-1} \mathrm{H}$ COSY NMR experiment, in which correlations between the following protons pairs could be observed: H-1 ",'” and H-2,",' $\left(\delta_{\mathrm{H}} 5.21 / 4.85\right), \mathrm{H}-2$ ',"' and H-3",'” $\left(\delta_{\mathrm{H}}\right.$ $4.85 / 5.14), \mathrm{H}-3$ "'," and H-4"'"' $\left(\delta_{\mathrm{H}} 5.14 / 4.95\right), \mathrm{H}-4$ "'," and

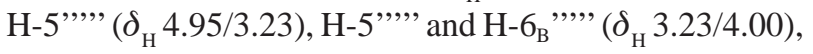
and $\mathrm{H}-5$ ",", and $\mathrm{H}-6_{\mathrm{A}}, ", "\left(\delta_{\mathrm{H}} 3.23 / 3.78\right)$. This sugar unit is completely acetylated as can be inferred on the basis of the following HMBC correlations $\left(\delta_{\mathrm{C}} / \delta_{\mathrm{H}}\right)$ between the acetate carbonyls and the above mentioned sugar protons: 171.6/4.85 (C=O/H-2,","'); 171.8/5.14 (C=O/H-3",",'); 171.6/4.95 (C=O/H-4,",'”); 172.5/3.78 (C=O/H-6 ${ }^{, ", ' ”) ; ~}$ and, $172.5 / 4.00\left(\mathrm{C}=\mathrm{O} / \mathrm{H}-6_{\mathrm{B}}{ }^{, "}{ }^{\prime \prime}\right)$. Carbons at $\mathrm{C}-5$ ' and $\mathrm{C}-5$ "' $\left(\delta_{\mathrm{C}} 159.5\right)$ showed long range correlations with the anomeric protons at $\delta_{\mathrm{H}} 4.93\left(\mathrm{H}-1\right.$ ") and $\delta_{\mathrm{H}} 4.89$ (H-1"'”), indicating the position of the other two sugar units. On the basis of these evidences, compound $\mathbf{4}$ was identified as $[2-[(2,3,4,6$-tetra- $O$-acetyl- $\beta$-D-glucopyranosyl $)$ oxy]-2-(2-methylpropyl)-1,4-dioxo-1,4-butanediyl]bis (oxymethylene-4,1-phenylene) bis- $\beta$-D-glucopyranoside, which was given the trivial name habenarioside as it is a mono-glucosylated derivative of habenariol. This compound can also be regarded as a tetra-acetate derivative of dactylorhin A, a natural product previously isolated from Dactylorhiza hatagirea D. Don. ${ }^{5}$ and from Gymnadenia conopsea ${ }^{23}$ From the latter species it was also described the presence of acetic and cinnamic esters of dactylorhin $\mathrm{A}$, all at the glucose connected to the $\mathrm{C}-2$ position of the malic acid. These findings indicate that further esters of dactylorhin A may be produced by Orchidaceae species.

Gitterman and co-workers ${ }^{13}$ demonstrated that in Cephalotaxus (Cephalotaxaceae) 2-isobutyl-malic acid is biosynthesized from L-leucine, and have $R$ configuration at C-2. Assuming that this is also the case in Orchidaceae, and based on structures of compounds already isolated from this family, a biosynthetic route is suggested for habenarioside (Scheme S1 - Supplementary Material). Accordingly, $2 R$-isobutyl-malic acid could be subjected to a sequence of esterification and glucosylation reactions to afford habenariol, militarin, dactylorhin A, and gymnoside III, as intermediates in the biosynthesis of habenarioside. This hypothetical sequence assumes that all intermediates have $2 R$ configuration in order to avoid the unlikely inversion/reversion of the $\mathrm{C}-2$ configuration. However, habenariol was reported to have $[\alpha]_{\mathrm{D}}^{25}+12^{\circ}$ and $2 S$ configuration. ${ }^{12}$ On the other hand, catalytic hydrogenation of militarin ${ }^{14}$, and comparison of the resulting 2-isobutyl malic acid with a synthetic standard, established its absolute stereochemistry as $2 R .{ }^{14}$ This data rises doubt about the published configuration for habenariol. Even though, it is possible to devise a pathway bypassing this compound, and use only $2 R$ intermediates. In such pathway, militarin would be produced via esterification of $2 R$-isobutyl-malic with gastrodin (Scheme $\mathrm{S} 1$ ) keeping the $R$ configuration at $\mathrm{C}-2$. Based on the above discussion we propose that habenarioside have $2 R$ configuration.

Malic acid derivatives $\mathbf{1}$ and $\mathbf{5}$ were previously isolated from Orchis militaris L., ${ }^{13,21}$ Dactylorhiza hatagirea D. Don, ${ }^{5}$ and Coeloglossum viride (L.) Hartm. var. bracteatum (Willd.), ${ }^{22}$ whilst 5, together with Gymnoside III (Scheme $\mathrm{S} 1$ ), were recently found in tubers of Gymnadenia conopsea $\mathrm{R} . \mathrm{Br}^{23}$ Zhang et al. ${ }^{24,25}$ reported that a fraction from the rhizomes of Coeloglossum viride rich in $\mathbf{1}$ and $\mathbf{5}$ significantly improved the memory of mice treated with scopolamine, cycloheximide or alcohol. These authors also demonstrated that this fraction protected neurons against injury by $\beta$-amyloid or $\mathrm{H}_{2} \mathrm{O}_{2}$, and suggested that these components could be of value in the treatment of Alzheimer's disease and other dementia.

Compounds $\mathbf{2 , 3}$ and $\mathbf{6}$ were isolated as yellow powders, and their UV spectra in $\mathrm{MeOH}$ exhibited absorptions consistent with those of flavonoids..$^{15}$ The ESI-MS in the negative ion mode of compound 2 showed a [M - H] ${ }^{-}$quasimolecular ion peak at $m / z 463$, while the ESI-MS in the positive ion mode of compounds $\mathbf{3}$ and $\mathbf{6}$ showed $[\mathrm{M}+\mathrm{Na}]^{+}$ quasi-molecular ion peaks at $\mathrm{m} / z 501$ and 663 , respectively. Their ${ }^{1} \mathrm{H}$ NMR spectra showed signals characteristic of glycosylated flavonoids, and comparison with published data allowed $\mathbf{2}$ to be identified as isoquercitrin ${ }^{16}, \mathbf{3}$ as isorhamnetin 3-O- $\beta$-D-glucopyranoside, ${ }^{16}$ and $\mathbf{6}$ as isorhamnetin 3,7-di- $O$ - $\beta$-D-glucopyranoside. ${ }^{17}$ Although isoquercitrin and isorhamnetin $3-O-\beta$-D-glucoside have been previously isolated from some Orchidaceae species, ${ }^{18-20}$ this is the first report on the occurrence of isorhamnetin 3,7-di-O- $\beta$-D-glucopyranoside in this family.

The present study contributes to the phytochemical characterization of Orchidaceae, disclosing the presence of a new compound and the occurrence of two known compounds reported for the first time in this family.

\section{Experimental}

\section{General experimental procedures}

TLC analysis were conducted on pre-coated silica gel G-60/F $\mathrm{F}_{254}(0.25 \mathrm{~mm}$, MERCK $)$ eluted with mixtures of $\mathrm{CHCl}_{3}: \mathrm{MeOH}: \mathrm{H}_{2} \mathrm{O}(65: 50: 1)$ and EtOAc:HOAc: $\mathrm{HCO}_{2} \mathrm{H}_{2} \mathrm{H}_{2} \mathrm{O}$ (100:11:11:26). Spots were visualized after spraying the plates with vanillin- $\mathrm{H}_{2} \mathrm{SO}_{4}$ or NP/PEG (Natural products-polyethylene glycol) reagents. ${ }^{15}$ Optical rotations were determined on a Perkin-Elmer 341 polarimeter. UV spectra were recorded in methanol on 
Table 1. ${ }^{1} \mathrm{H}$ and ${ }^{13} \mathrm{C}$ NMR data for compound $4\left(\mathrm{CD}_{3} \mathrm{OD}, 400\right.$ and $100 \mathrm{MHz}$, respectively)

\begin{tabular}{|c|c|c|c|}
\hline $\mathrm{H}$ & $\delta_{\mathrm{H}}, J /(\mathrm{Hz})$ & $\mathrm{C}$ & $\delta_{\mathrm{c}}$ \\
\hline- & - & $\mathrm{C}-1$ & 173.3 \\
\hline- & - & $\mathrm{C}-2$ & 81.7 \\
\hline $\mathrm{H}-3_{\mathrm{A}}$ & $3.04 \mathrm{~d}(17.9)$ & $\mathrm{C}-3$ & 44.8 \\
\hline $\mathrm{H}-3_{\mathrm{B}}$ & $2.98 \mathrm{~d}(17.9)$ & & \\
\hline$-\quad B$ & - & $\mathrm{C}-4$ & 172.1 \\
\hline $\mathrm{H}-5$ & $1.61 \mathrm{dd}(7.2,14.1)$ & $\mathrm{C}-5$ & 50.2 \\
\hline H-6 & $1.73 \mathrm{~m}$ & C-6 & 24.9 \\
\hline $\mathrm{H}-7$ & $0.77 \mathrm{~d}(6.4)$ & $\mathrm{C}-7$ & 23.6 \\
\hline $\mathrm{H}-8$ & $0.84 \mathrm{~d}(6.4)$ & C-8 & 25.0 \\
\hline \multicolumn{4}{|c|}{ 1-O-(4- $\beta$-D-glucopyranosyloxy)benzyl moiety } \\
\hline $\mathrm{H}-1_{\mathrm{A}}{ }^{\prime}$ & $5.10 \mathrm{~d}(12.0)$ & $\mathrm{C}-1$ ' & \\
\hline $\mathrm{H}-1_{\mathrm{B}}^{\mathrm{A}}$, & $5.03 \mathrm{~d}(12.0)$ & & 68.1 \\
\hline- & - & $\mathrm{C}-2$ & \\
\hline $\mathrm{H}-3^{\prime}, 7^{\prime}$ & $7.30 \mathrm{~d}(8.7)$ & $\mathrm{C}-3^{\prime}, 7^{\prime}$ & 130.8 \\
\hline $\mathrm{H}-4^{\prime}, 6$ ' & $7.11 \mathrm{~d}(8.6)$ & $\mathrm{C}-4^{\prime}, 6^{\prime}$ & 131.7 \\
\hline- & - & $\mathrm{C}-5$ & 118.1 \\
\hline Glc-1” & $4.93 \mathrm{~d}(7.8)$ & Glc-1" & 159.5 \\
\hline Glc-2” & $3.43 \mathrm{~m}$ & Glc-2" & 102.3 \\
\hline Glc-3” & $3.45 \mathrm{~m}$ & Glc-3”, & 78.3 \\
\hline Glc-4” & $3.46 \mathrm{~m}$ & Glc-4" & 75.1 \\
\hline Glc-5”, & $3.40 \mathrm{~m}$ & Glc-5" & 78.1 \\
\hline Glc-6," & $3.88 \mathrm{dd}(2.6,12.0)$ & Glc-6", & 71.5 \\
\hline Glc-6 $6_{\mathrm{B}}^{\mathrm{A}}$, & $3.70 \mathrm{dd}(4.6,12.0)$ & & 62.7 \\
\hline \multicolumn{4}{|c|}{ 4-O-(4- $\beta$-D-glucopyranosyloxy)benzyl moiety } \\
\hline $\mathrm{H}-1, "$, & $5.06 \mathrm{~d}(12.0)$ & $\mathrm{C}-1$, & 67.6 \\
\hline $\mathrm{H}-1_{\mathrm{B}}^{\mathrm{A}}$, & $4.91 \mathrm{~d}(12.0)$ & & \\
\hline$-{ }^{B}$ & - & $\mathrm{C}-2{ }^{\prime}$ & 131.1 \\
\hline H-3",",7", & $7.29 \mathrm{~d}(8.7)$ & $\mathrm{C}-3^{\prime \prime}, 7^{\prime \prime}$ & 131.8 \\
\hline $\mathrm{H}-4 ",{ }^{\prime},{ }^{\prime}$, & $7.09 \mathrm{~d}(8.6)$ & C-4"', 6", & 118.0 \\
\hline- & - & C-5”" & 159.5 \\
\hline Glc-1"”, & $4.89 \mathrm{~d}(7.7)$ & Glc-1"', & 102.5 \\
\hline Glc-2"', & $3.43 \mathrm{~m}$ & Glc-2"', & 78.3 \\
\hline Glc-3”"' & $3.45 \mathrm{~m}$ & Glc-3"'" & 75.1 \\
\hline Glc-4”"' & $3.46 \mathrm{~m}$ & Glc-4,"' & 78.1 \\
\hline Glc-5"”, & $3.40 \mathrm{~m}$ & Glc-5"', & 71.5 \\
\hline Glc-6,",' & $3.89 \mathrm{dd}(2.2,12.0)$ & Glc-6"', & 62.7 \\
\hline Glc- $6_{B}^{A}$, & $3.69 \mathrm{dd}(5.4,12.0)$ & & \\
\hline \multicolumn{4}{|c|}{$2-O$-(2,3,4,6-tetra-acetate)- $\beta$-D-glucopyranosyl moiety } \\
\hline Glc-1",", & $5.21 \mathrm{~d}(8.0)$ & Glc-1",", & 98.6 \\
\hline Glc-2","” & $4.85 \mathrm{dd}(7.9,9.7)$ & Glc-2"”,' & 72.8 \\
\hline Glc-3",", & $5.14 \mathrm{dd}(1.0,9.8)$ & Glc-3"',' & 74.2 \\
\hline Glc-4",", & $4.95 \mathrm{dd}(1.0,9.8)$ & Glc-4",", & 69.7 \\
\hline Glc-5",", & $3.23 \operatorname{td}(3.0,9.9)$ & Glc-5"', & 72.4 \\
\hline Glc-6 $",, "$ & $4.00 \mathrm{dd}(3.6,12.4)$ & Glc-6",", & 62.8 \\
\hline Glc-6 ${ }_{\mathrm{P}}^{\mathrm{A}},$, & $3.78 \mathrm{dd}(2.4,12.4)$ & & \\
\hline Glc-2",'”-COCH$\underline{H}_{3}$ & $1.95 \mathrm{~s}$ & Glc-2","'- $\mathrm{COCH}_{3}$ & $171.6 / 20.9$ \\
\hline Glc-3"'"'-COC $\underline{\vec{H}}_{3}^{3}$ & $1.97 \mathrm{~s}$ & Glc-3"'”- $-\underline{\bar{C}} \underline{\bar{C}} \mathrm{H}_{3}$ & $171.8 / 20.7$ \\
\hline Glc-4","'-COC $\underline{H}_{3}$ & $2.01 \mathrm{~s}$ & Glc-4","'- $\underline{\mathrm{CO}} \mathrm{CH}_{3}$ & $171.5 / 20.9$ \\
\hline 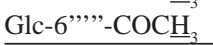 & $2.00 \mathrm{~s}$ & Glc-6""'- $-\underline{\mathrm{C}} \underline{\underline{\mathrm{C}}} \mathrm{H}_{3}^{3}$ & $172.5 / 20.8$ \\
\hline
\end{tabular}

* Chemical shifts $(\delta)$ are shown in ppm, and coupling constants $(J)$ are in Hz. Several multiplicities could not be determined due to spectral complexity and/or signal superimposition.

a Beckman DU ${ }^{\circledR}$ Series 600 spectrophotometer, whilst infrared spectra were measured in $\mathrm{KBr}$ pellets on a Shimadzu FTIR-8400 instrument. ${ }^{1} \mathrm{H}$ NMR $(400 \mathrm{MHz})$, ${ }^{13} \mathrm{C}$ NMR (100 MHz), DEPT, HMQC and HMBC experiments were carried out using a Bruker DRX 400 spectrometer. ESI-MS were recorded on a Thermo Finnigan
LCQ-Advantage spectrometer, whilst high resolution mass measurements were obtained using a Micromass Q-TOF Micro ${ }^{\text {TM }}$ instrument equipped with an ESI source operated in the positive ion mode. Extract, fractions and compounds were analyzed by HPLC using a Shim-pack ${ }^{\oplus}$ $\mathrm{C}_{18}$ column $(5 \mu \mathrm{m}, 250 \mathrm{~mm} \times 4.6 \mathrm{~mm}$ i.d. $)$ in a Shimadzu 
chromatograph equipped with a LC10AD pump and a diode-array detector (SPD M10A). The column was pumped with $\mathrm{MeOH}: \mathrm{H}_{2} \mathrm{O}(10: 90 \rightarrow 70: 30$ in $30 \mathrm{~min}$; $70: 30 \rightarrow 100$ in $5 \mathrm{~min}$ ) at a flow rate of $1 \mathrm{~mL} \mathrm{~min}^{-1}$ and the effluent detected at wavelengths between 200 and $400 \mathrm{~nm}$. Semi-preparative HPLC purifications were carried out on a Shimadzu chromatograph equipped with a LC6AD pump and a dual wavelength detector (SPD10A), using a Shim-

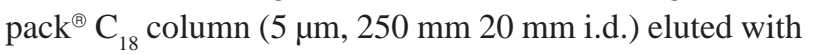
mixtures of $\mathrm{MeOH}: \mathrm{H}_{2} \mathrm{O}$ or $\mathrm{MeCN}: \mathrm{H}_{2} \mathrm{O}$ at a flow rate of $10 \mathrm{~mL} \mathrm{~min}^{-1}$ and detection at $230 \mathrm{~nm}$ and $254 \mathrm{~nm}$.

\section{Plant material}

Specimens of Habenaria petalodes Lindl. were collected in Belo Horizonte-MG, Brazil, in April 2004. The plant material was identified by Prof. João Renato Stehmann of the Universidade Federal de Minas Gerais, Belo Horizonte-MG, Brazil. A voucher specimen was deposited in the Herbarium BHCB (Instituto de Ciências Biológicas, Belo Horizonte-MG, Brazil) under the code BHCB-88339.

\section{Extraction and isolation}

Whole fresh plants $(185 \mathrm{~g})$ were chopped into small pieces and macerated in ethanol for 3 weeks at room temperature. After filtration and solvent evaporation, $8 \mathrm{~g}$ of the extract were obtained. An aliquot $(6.2 \mathrm{~g})$ was suspended in $100 \mathrm{~mL} \mathrm{MeOH}: \mathrm{H}_{2} \mathrm{O}$ (1:1), and extracted with $\mathrm{CH}_{2} \mathrm{Cl}_{2}(3 \times 100 \mathrm{~mL})$ to afford an organic fraction $(610 \mathrm{mg})$ and a hydroalcoholic fraction $(4.7 \mathrm{~g})$. The latter was concentrated to dryness under reduced pressure, and the residue dissolved in water. The solution was subjected to solid phase extraction using Sep-Pak ${ }^{\circledR} \mathrm{C}_{18}$ cartridges. The loaded cartridge was eluted with water, and then with methanol, to yield an aqueous ( $3.9 \mathrm{~g}$ ) and a methanolic $(756 \mathrm{mg})$ fraction. A portion of the methanolic fraction $(669 \mathrm{mg})$ was subjected to semi-preparative HPLC with linear gradient elution with $\mathrm{MeOH}: \mathrm{H}_{2} \mathrm{O}$ from 30 to $70 \%$ over $60 \mathrm{~min}$, and detection at $210 \mathrm{~nm}$ and $254 \mathrm{~nm}$, to yield 29 sub-fractions. Sub-fraction $13(6.5 \mathrm{mg})$ was subjected to column chromatography on Sephadex LH-20, eluted with $\mathrm{MeOH}$ to afford compound $2(5 \mathrm{mg})$. Sub-fraction 7 $(6.6 \mathrm{mg})$ was purified by semi-preparative HPLC in a RP-18 column eluted with $\mathrm{MeCN}: \mathrm{H}_{2} \mathrm{O}$ 10:90 $\rightarrow$ 50: 50 in $60 \mathrm{~min}$, at a flow rate of $10 \mathrm{~mL} \mathrm{~min}^{-1}$, to yield $4 \mathrm{mg}$ of compound $\mathbf{1}$. Sub-fraction $17(23.9 \mathrm{mg})$ was purified by semi-preparative HPLC in a RP-18 column eluted with $\mathrm{MeCN}: \mathrm{H}_{2} \mathrm{O}$ 50:50 $\rightarrow$ 60: 40, in $40 \mathrm{~min}$ at a flow rate of $10 \mathrm{~mL} \mathrm{~min}^{-1}$, to yield $8 \mathrm{mg}$ of $\mathbf{3}$. The second portion of the methanolic fraction $(87 \mathrm{mg}$ ) was subjected to semi-preparative HPLC with linear gradient elution from $10 \% \mathrm{MeOH}-\mathrm{H}_{2} \mathrm{O}$ to $100 \%$ $\mathrm{MeOH}$ over $40 \mathrm{~min}$, to afford $4(22.5 \mathrm{mg})$ and $5(5 \mathrm{mg})$. The aqueous fraction from SPE $(2.0 \mathrm{~g})$ was divided into equal portions and chromatographed on a Sephadex LH-20 column $\left(470 \times 30 \mathrm{~mm}\right.$ i.d.) eluted with $\mathrm{MeOH}: \mathrm{H}_{2} \mathrm{O}(1: 1)$, to give 24 sub-fractions. Compound $6(7 \mathrm{mg})$ precipitated from the fraction 10 .

\section{Characterization of the sugar moieties}

Compound $4(2 \mathrm{mg})$ was hydrolyzed in 0.5 TFA at $100{ }^{\circ} \mathrm{C}$ for $4 \mathrm{~h}$. To the reaction mixture was added methanol $(0.5 \mathrm{~mL})$ and the solution evaporated to dryness under a stream of nitrogen. This operation was repeated to completely remove the TFA. To the resulting solid were added $0.3 \mathrm{~mL}$ of a solution of $1 \mathrm{mg} / \mathrm{ml}$ aqueous $\mathrm{NaBH}_{4}$ and the reaction kept at $25^{\circ} \mathrm{C}$. After $30 \mathrm{~min}$ the reaction was stopped by addition of $0.5 \mathrm{~mL} 10 \% \mathrm{AcOH}$ in $\mathrm{MeOH}$, and the reaction mixture evaporated to dryness. The later steps, that is, addition of acidified methanol and evaporation, were repeated twice. The residue was acetylated by adding $0.1 \mathrm{~mL}$ of $\mathrm{Ac}_{2} \mathrm{O}$ and heating at $100{ }^{\circ} \mathrm{C}$ for $30 \mathrm{~min}$. Toluene $(0.5 \mathrm{~mL})$ was added to the reaction mixture and the solution evaporated under a stream of nitrogen at $90{ }^{\circ} \mathrm{C}$. This operation was repeated three to four times to completely remove the acetic anhydride. The residue was then partitioned $(3 \times)$ between $\mathrm{H}_{2} \mathrm{O}$-EtOAc (1:1) and the organic phase was pooled, concentrated and dissolved in $0.2 \mathrm{~mL}$ of EtOAc. Control experiments with sugar standards were run in parallel. The alditol acetate solutions thus obtained were analyzed in a Shimadzu GC-17A gas chromatograph in line with a QP5050A mass spectrometer. One microliter of each solution was injected in a capillary column DB-5 (30 m $\times$ $0.25 \mathrm{~mm}$ i.d.), using helium as carrier gas $\left(1.5 \mathrm{~mL} \mathrm{~min}^{-1}\right)$ and the following temperature programming: 100 to $200^{\circ} \mathrm{C}$ in $20 \mathrm{~min}, 200-300{ }^{\circ} \mathrm{C}$ in $5 \mathrm{~min}$ and keeping at $300{ }^{\circ} \mathrm{C}$ for $5 \mathrm{~min}$. The injector and detector were kept at $230^{\circ} \mathrm{C}$ and $250{ }^{\circ} \mathrm{C}$, respectively. ${ }^{27}$ Under these conditions the retention times of the alditol acetates obtained from the standard sugars were: ribose (17.77 $\mathrm{min})$, arabinose (17.95 $\mathrm{min})$, xylose (18.34 min), mannose (21.78 $\mathrm{min})$, glucose (21.88 $\mathrm{min})$, and galactose (21.96 $\mathrm{min})$.

\section{Loroglossin (1)}

$$
[\alpha]_{\mathrm{D}}{ }^{25}-28.0^{\circ}\left(\mathrm { MeOH } , c \text { 0.23) } \left\{\text { Lit. }^{14}[\alpha]_{\mathrm{D}}{ }^{25}-34.0\right.\right.
$$
$(\mathrm{MeOH}, c=0.36)\}, \mathrm{UV} \lambda_{\max }^{\mathrm{MeOH}} / \mathrm{nm}(\log \varepsilon): 201$ (4.22), 221 (4.18), 268 (3.42); ${ }^{1} \mathrm{H}$ NMR ( $\left.\mathrm{CD}_{3} \mathrm{OD}, 400 \mathrm{MHz}\right): \delta_{\mathrm{H}} 0.80$ $(3 \mathrm{H}, \mathrm{d}, J 6.5 \mathrm{~Hz}, \mathrm{H}-7), 0.94(3 \mathrm{H}, \mathrm{d}, J 6.5 \mathrm{~Hz}, \mathrm{H}-8), 1.68(1 \mathrm{H}$, m, H-6), 1.91 (2H, m, H-5), 4.36 (1H, s, H-3), 4.97 (d, J 7.4 
$\mathrm{Hz}, \mathrm{H} 1$ ”, H1'”), 5.08, 4.97 (2H, d, $J_{\mathrm{A}}=J_{\mathrm{B}} 11.8 \mathrm{~Hz}, \mathrm{H}-1^{\prime}{ }_{\mathrm{A}}$ and $\left.\mathrm{H}-1{ }_{\mathrm{B}}\right), 5.09,4.98\left(2 \mathrm{H}, \mathrm{d}, J_{\mathrm{A}}=J_{\mathrm{B}} 12.0 \mathrm{~Hz}, \mathrm{H}-1{ }^{\prime}{ }_{\mathrm{A}}{ }_{\mathrm{A}}\right.$ and H-1 '” $\left.{ }_{\mathrm{B}}\right), 7.30\left(2 \mathrm{H}, \mathrm{d}, J 8.6 \mathrm{~Hz}, \mathrm{H}-3^{\prime}, 7^{\prime}\right), 7.18$ (2H, d, $J 8.8$ Hz, H-3'”, 7'”), 7.12 (2H, d, J 8.6 Hz, H-4',6'), 7.07 (2H, d, J $8.8 \mathrm{~Hz}, \mathrm{H}-4$ "',6" "), 3.45 (m, H-2", H-2'”'/H-3", H-3"'”/H-5", H-5"'”), 3.40 (m, H-4", H-4"'), 3.71 (m, H-6 ", H-6 '"'), 3.89 (m, H-6 ${ }_{\mathrm{B}}$ ", H- $\left.6_{\mathrm{B}}{ }^{\prime \prime \prime}\right)$ ); ${ }^{13} \mathrm{C}$ NMR (CD $\left.\mathrm{OD}, 100 \mathrm{MHz}\right): \delta_{\mathrm{C}} 24.2$ (C-8), 24.7 (C-7), 25.3 (C-6), 45.3 (C-5), 62.9 (C-6", C-6"'”), 68.2 (C-1', C-1'”), 71.5 (C-4", C-4"'”), 75.1 (C-2", C-2"'), 77.5 (C-3), 78.1/78.3 (C-3"; C-3'”'/C-5", C-5'”'), 81.1 (C2), 102.5 (C-1", C-1"'”), 118.0/117.9 (C-4',6'; C-4"',6”"), 129.5/130.6 (C-2', C-2'”), 131.7/ 131.4 (C-3',7'; C-3"', 7'”), 159.4/159.5 (C-5', C-5'”), 172.9 (C-4), 174.9 (C-1). ESI-MS (positive mode) $[\mathrm{M}+\mathrm{Na}]^{+}(\mathrm{m} / \mathrm{z} 765)$.

\section{Militarin (5)}

$[\alpha]_{\mathrm{D}}{ }^{25}-41.0^{\circ}(\mathrm{MeOH}, c 0.23)\left\{\right.$ Lit. ${ }^{14}[\alpha]_{\mathrm{D}}{ }^{25}-47.0$ $(\mathrm{MeOH}, c=0.78)\}, \mathrm{UV}(\mathrm{MeOH}) \lambda_{\max } / \mathrm{nm}(\log \varepsilon): 203$ (4.19), 219 (4.10), 269 (3.47), IR (KBr) $v_{\max } / \mathrm{cm}^{-1}: 3410$ (OH), 2924 (aliphatic), 2855 (aliphatic), 1612 (aromatic), 1512 (aromatic), 1736 (carbonyl), 1458 (aromatic), 1234 (C-O), 1076 (C-O), 1045 (C-O); ${ }^{1} \mathrm{H}$ NMR ( $\mathrm{CD}_{3} \mathrm{OD}, 400$ MHz): $\delta_{\mathrm{H}} 0.82(3 \mathrm{H}, \mathrm{d}, J 6.5 \mathrm{~Hz}, \mathrm{H}-7), 0.93(3 \mathrm{H}, \mathrm{d}, J 6.5$ $\mathrm{Hz}, \mathrm{H}-8), 1.61$ (2H, m, H-5), 1.72 (1H, m, H-6), 2.65, $2.95\left(1 \mathrm{H}, \mathrm{d}, J_{\mathrm{A}}=J_{\mathrm{B}} 15.6 \mathrm{~Hz}, \mathrm{H}-3_{\mathrm{A}}\right.$ and $\left.\mathrm{H}-3_{\mathrm{B}}\right), 5.01(4 \mathrm{H}, \mathrm{s}$, H-1' and H-1'"), 7.30-7.25 (4H, m, H-3',7'; H-3'", 7'"'), 7.11-7.07 (4H, m, H-4',6'; H-4'”,6'"), 4.91 (d, J 7.4 Hz, H-1", H-1'”'), 3.45 (m, H-2", H-2'"'/ H-3", H-3"'"/ H-5",

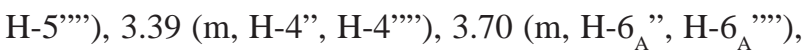
3.87 (m, H- $6_{\mathrm{B}}{ }^{\prime}, \mathrm{H}-6_{\mathrm{B}}{ }^{, "}$ )'); ${ }^{13} \mathrm{C}$ NMR (CD $\left.\mathrm{OD}, 100 \mathrm{MHz}\right): \delta_{\mathrm{C}}$ 22.5 (C-7), 23.3 (C-8), 23.7 (C-6), 44.8 (C-3), 47.7 (C-5), 61.1 (C-6", C-6"”), 65.8 (C-1'”), 66.6 (C-1'), 70.0 (C-4", C-4"”'), 73.5 (C-2", C-2"'”), 75.3 (C-2), 76.6/76.7 (C-3"; C-3"'”/C-5", C-5"'), 100.9 (C-1", C-1"'), 116.4 (C-4',6'; C-4"',6"'), 129.4 (C-2', C-2'”), 129.6/129.8 (C-3',7'; C-3"',7'”), 157.8 (C-5', C-5”'), 170.2 (C-4), 174.6 (C-1) ). ESI-MS (positive mode) $[\mathrm{M}+\mathrm{Na}]^{+}(\mathrm{m} / \mathrm{z}, 749)$.

\section{Habenarioside (4)}

Resinous solid; $[\alpha]_{\mathrm{D}}{ }^{25}-30.0$ (c $\left.0.16, \mathrm{MeOH}\right)$; UV (MeOH) $\lambda_{\max } / \mathrm{nm}(\log \varepsilon): 224$ (3.76) and 271 (3.28); IR $v_{\max } / \mathrm{cm}^{-1}: 3433(\mathrm{OH}), 2959$ (aliphatic), 2874 (aliphatic), 1612 (aromatic), 1512 (aromatic), 1755 (carbonyl), 1072 (C-O), 1042 (C-O); ${ }^{1} \mathrm{H}$ and ${ }^{13} \mathrm{C}$ NMR spectral data, see Table 1; ESI-MS $\mathrm{m} / z$ positive mode: $1079[\mathrm{M}+\mathrm{Na}]^{+}, 1095$ $[\mathrm{M}+\mathrm{K}]^{+}$; HRMS: $1079.3578[\mathrm{M}+\mathrm{Na}]^{+}$(calc. for $\left[\mathrm{C}_{48} \mathrm{H}_{64} \mathrm{O}_{26}+\mathrm{Na}\right]^{+}:$: 1079.3584).

\section{Supplementary Information}

Supplementary data including IR, LC-DAD, ${ }^{1} \mathrm{H}$ and ${ }^{13} \mathrm{C}$ NMR and HRMS spectra are available free of charge at http://jbcs.sbq.org.br as PDF file.

\section{Acknowledgments}

The authors wish to thank CAPES for a fellowship (B. B. Cota) and FIOCRUZ for financial support.

\section{References}

1. Giulietti, A. M.; Harley, R. M.; Queiroz, L.P.; Wanderley, M. G. L; Van Den Berg, C.; Conserv. Biol. 2005, 19, 632.

2. Tagushi, H.; Yosioka, I.; Yamasaki, K.; Kim, I. H.; Chem. Pharm. Bull. 1981, 29, 55.

3. Noda, N.; Kobayashi, Y.; Miyahara, K.; Fukahori, S.; Phytochemistry 1995, 39, 1247.

4. Lin, J. H.; Liu, Y. C.; Hau, J. P.; Wen, K. C.; Phytochemistry 1996, 42, 549.

5. Kizu, H.; Kaneko, E. I.; Tomimori, T.; Chem. Pharm. Bull. 1999, 47, 1618.

6. Sheng-Yang, H.; Shi, J. G.; Mo, S. Y.; Wang, S.J.; Yang, Y. C.; J. Asian Nat. Prod. Res. 2004, 6, 49.

7. Williams, C. A.; De Brito, A. L.; Toscano, Harborne, J. B.; Eagles, J.; Waterman, P. G.; Phytochemistry 1994, 37, 1045.

8. Reis, M. G.; Singer, R. B.; Gonçalves, R.; Marsaioli, A. J.; Nat. Prod. Comm. 2006, 1, 757.

9. Pabst, G. F. J.; Dungs, F.; Orchidaceae Brasiliensis. Brücke Verlag: Hildesheim, 1975.

10. NAPRALERT (Natural Producst Alert) Database; http://www. napralert.org/, accessed in January 2008.

11. Johnson, M. K.; Alexander, K. E.; Lindquist, N.; Loo, G.; Comp. Biochem. Physiol. C: Pharmacol. Toxicol. 1999, 122, 211.

12. Wilson, D. M.; Fenical, W.; Hay, M.; Lindquist, N.; Bolser, R.; Phytochemistry 1999, 50, 1333.

13. Gitterman, A.; Parry, R. J.; Dufresne, R.F.; Sternbach, D. D.; Cabelli, M. D.; J. Am. Chem. Soc. 1980, 102, 2074.

14. Aasen, A.; Behr, D.; Leander, K.; Acta Chem. Scand., B 1975, 29, 1002.

15. Wagner, H. M.; Bladt, S.; Zgainski, E. M.; Plant Drug Analysis, 1st ed., Springer: Berlin, 1984.

16. Güvenalp, Z.; Demirezer, L.O.; Turk. J. Chem. 2005, 29, 163.

17. Yeskaliyeva, B.; Mesaik, M. A.; Abbaskhan, A.; Kulsoom, A.; Burasheva, G. S. H.; Abilov, Z. H. A.; Choudhary, M. I.; AttaUr-Rahman; Phytochemistry 2006, 67, 2392.

18. Katsunori, S.; Takashi, T.; Phytochemistry 2002, 61, 339.

19. Tira, S.; Phytochemistry 1971, 10, 1975. 
20. Pagani, F.; Bull. Chim. Farm. 1976, 115, 407.

21. Appolonia, C.; Marston, A.; Hostettmann, K.; J. Nat. Prod. 1986, 49, 725.

22. Huang, S. Y.; Li, G. Q.; Shi, J. G.; Mo, S. Y.; J. Asian Nat. Prod. Res. 2004, 6, 49.

23. Morikawa, T.; Xie, H.; Matsuda, H.; Yoshikawa, M. J. Nat. Prod. 2006, 69, 881.

24. Zhang, D.; Shi, J.; Wang, Y.; Zhang, D.; Gao, M.; Yang, Y.; Huang, S.; PCT/CN2003/001155. 2004 (WO/2004/058244).
25. Zhang, D.; Liu, G.; Shi, J. G.; Zhang, J. J.; Basic Clin. Pharmacol. Toxicol. 2006, 98, 55.

26. Mabry, T. J.; Markham, K. R.; Thomas, M. B.; The Systematic Identification of Flavonoids, Springer Verlag: New York, 1970.

27. Stockholm University. Structural analysis of carbohydrates. Kontaktuppgifter: Stockholm. Available at: http://www.casper. organ.su.se/sop/, accessed in February 2008.

Received: December 17, 2007

Web Release Date: July 11, 2008 


\section{Chemical Constituents of Habenaria petalodes Lindl. (Orchidaceae)}

\section{Betania B. Cota, ${ }^{a}$ Alviclér Magalhães, ${ }^{b}$ Adriano M. C. Pimenta, ${ }^{c}$ Ezequias P. Siqueira, ${ }^{a}$ Tânia M. A. Alves ${ }^{a}$ and Carlos L. Zani ${ }^{*}, a$}

${ }^{a}$ Laboratório de Química de Produtos Naturais, CPqRR-FIOCRUZ, Av. Augusto de Lima, 1715, 30190-002 Belo Horizonte-MG, Brazil

${ }^{b}$ Instituto Tecnológico de Fármacos, FIOCRUZ, Rua Sizenando Nabuco, 100, 21041-250 Rio de Janeiro-RJ, Brazil

${ }^{c}$ Departamento de Bioquímica e Imunologia, ICB - UFMG. Av. Antônio Carlos, 6.627,

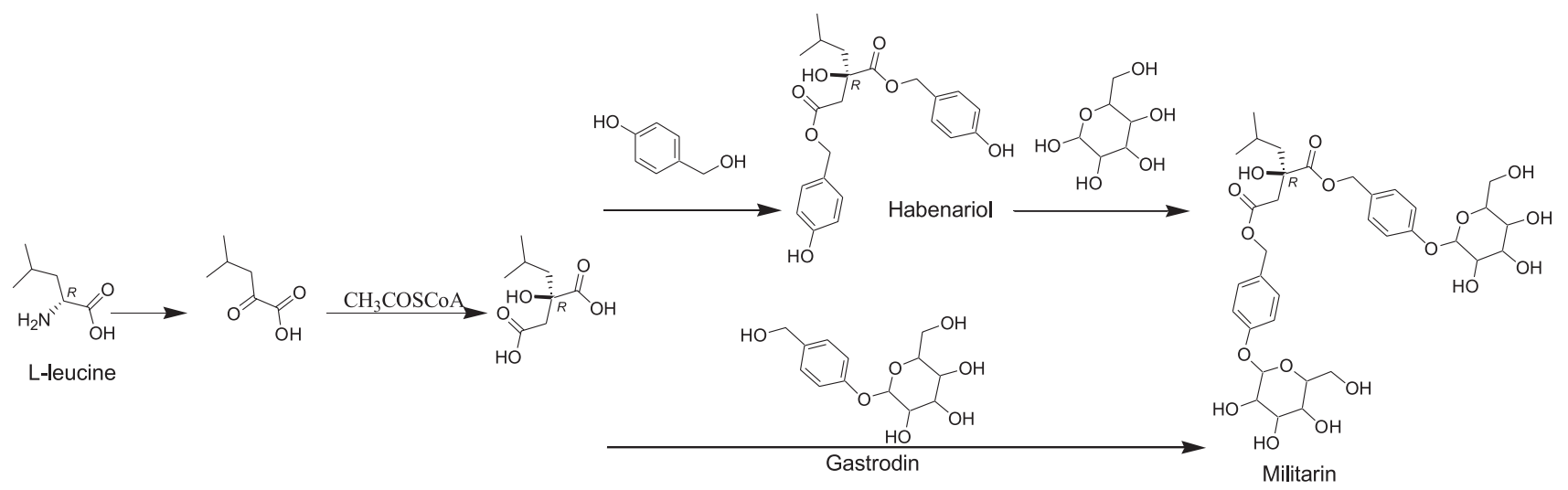

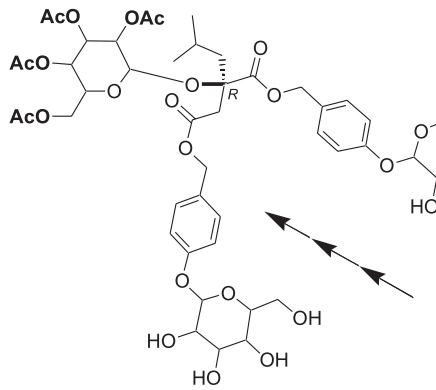

Habenarioside
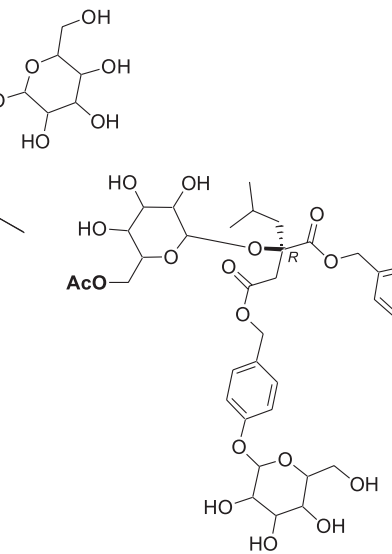

Gymnoside III

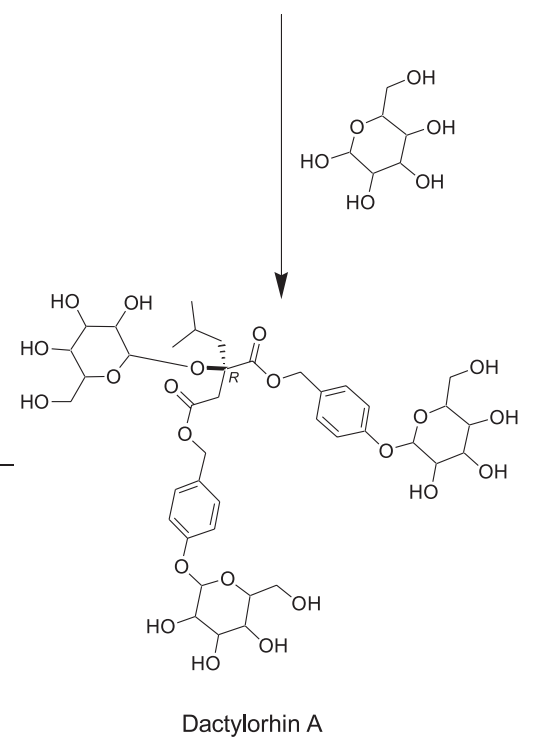

Scheme S1. Proposed biosynthetic routes to habenarioside.

*e-mail: zani@cpqrr.fiocruz.br 


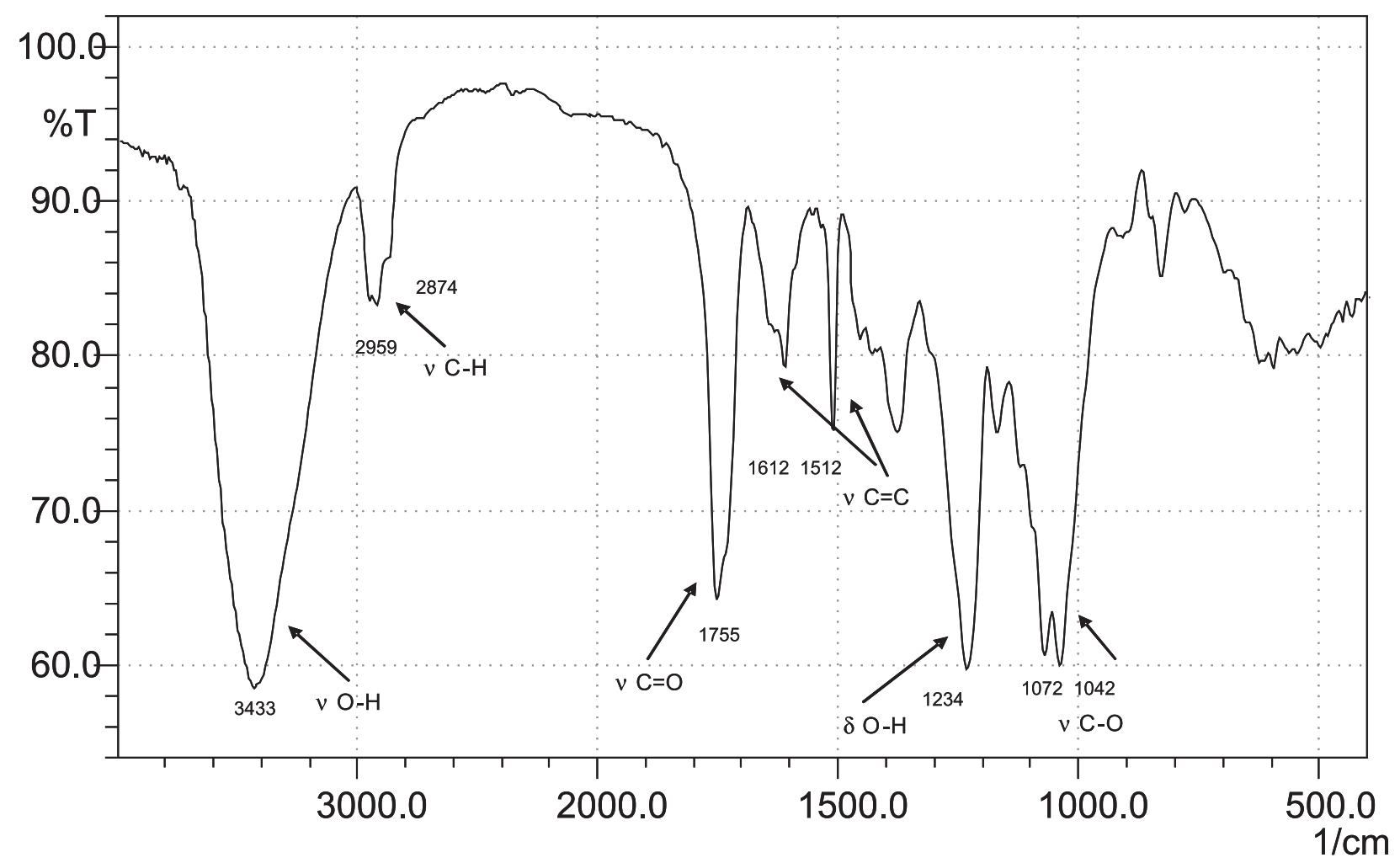

Figure S1. Infrared spectrum of $4\left(\mathrm{KBr}, \mathrm{cm}^{-1}\right)$.

\section{$\mathrm{P} 17+\mathrm{Nal}(1: 3)$}

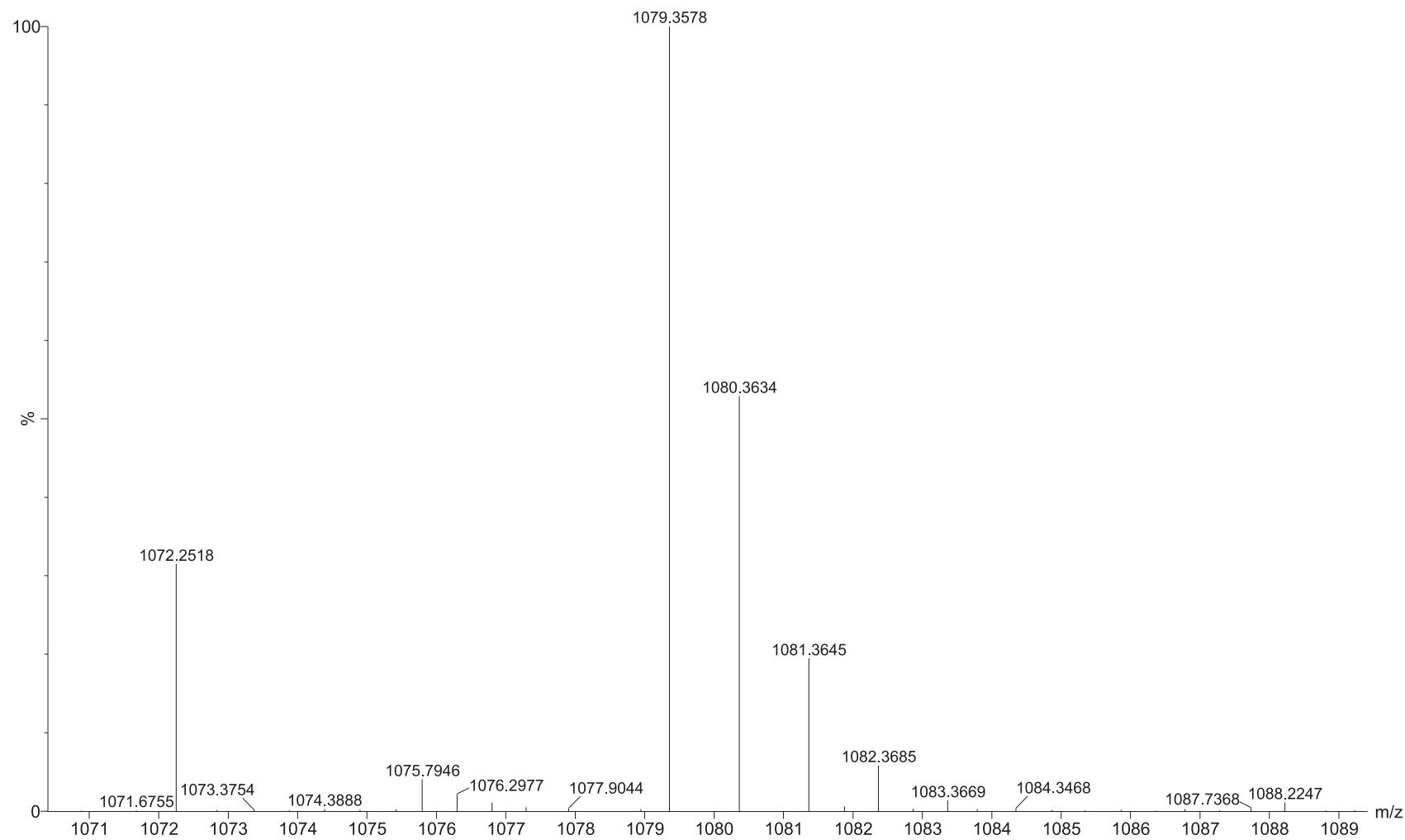

Figure S2. ESI-Q/TOFMS spectrum of 4. 


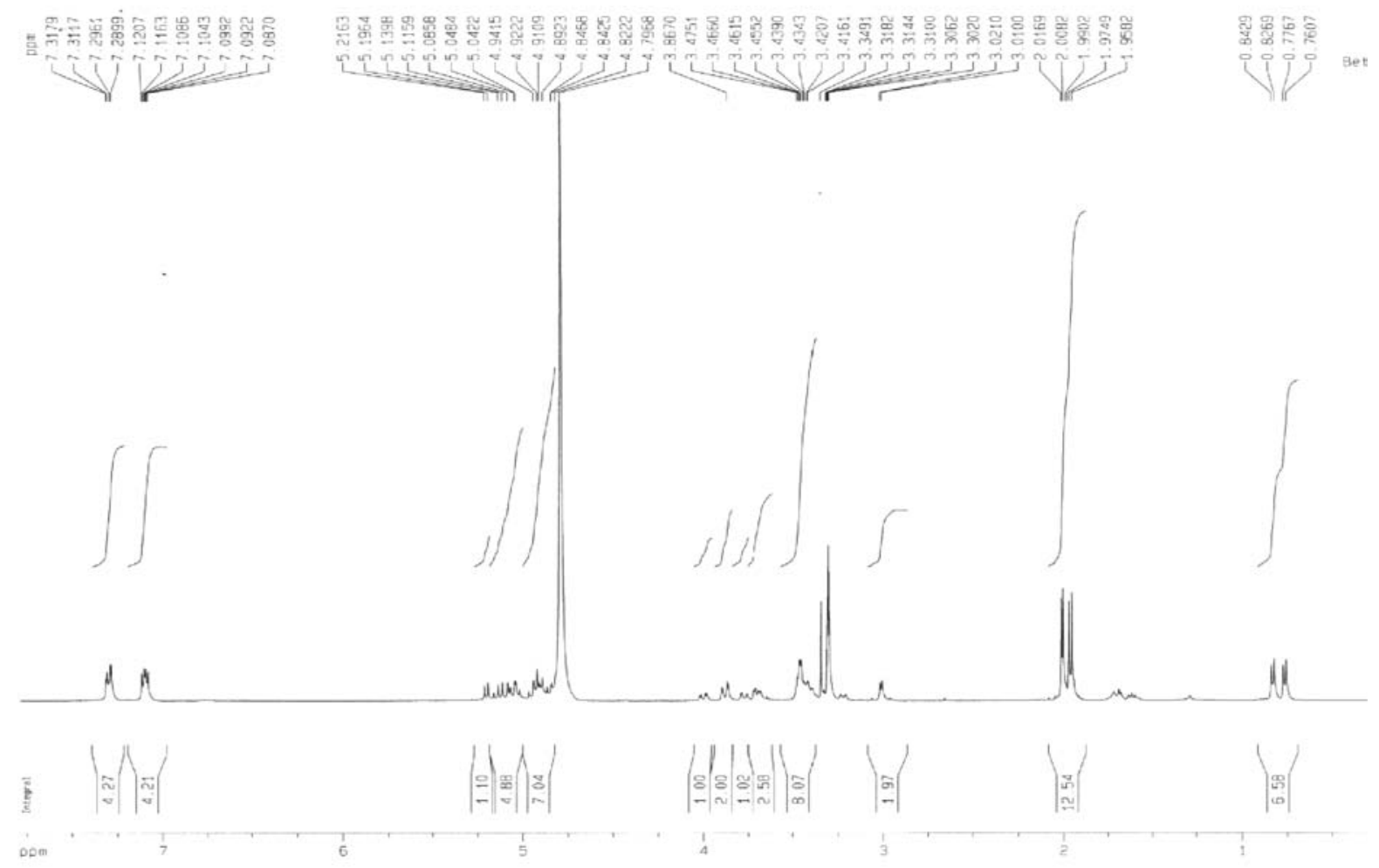

Figure S3. ${ }^{1} \mathrm{H}$ NMR spectrum of $\mathbf{4}\left(\mathrm{CD}_{3} \mathrm{OD}, \mathrm{ppm}\right)$.

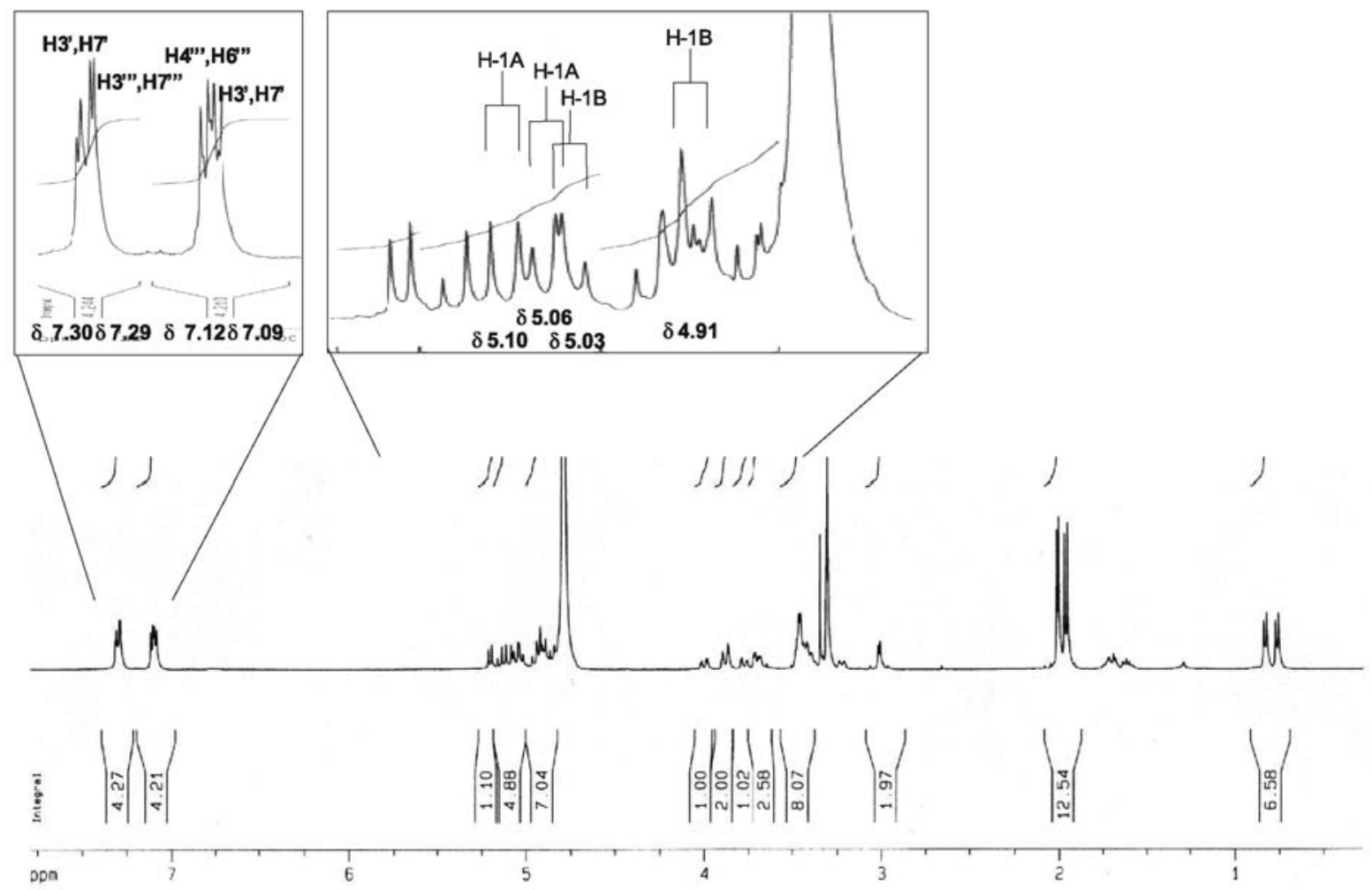

Figure S4. ${ }^{1} \mathrm{H}$ NMR spectrum of $\mathbf{4}\left(\mathrm{CD}_{3} \mathrm{OD}\right.$, ppm). 


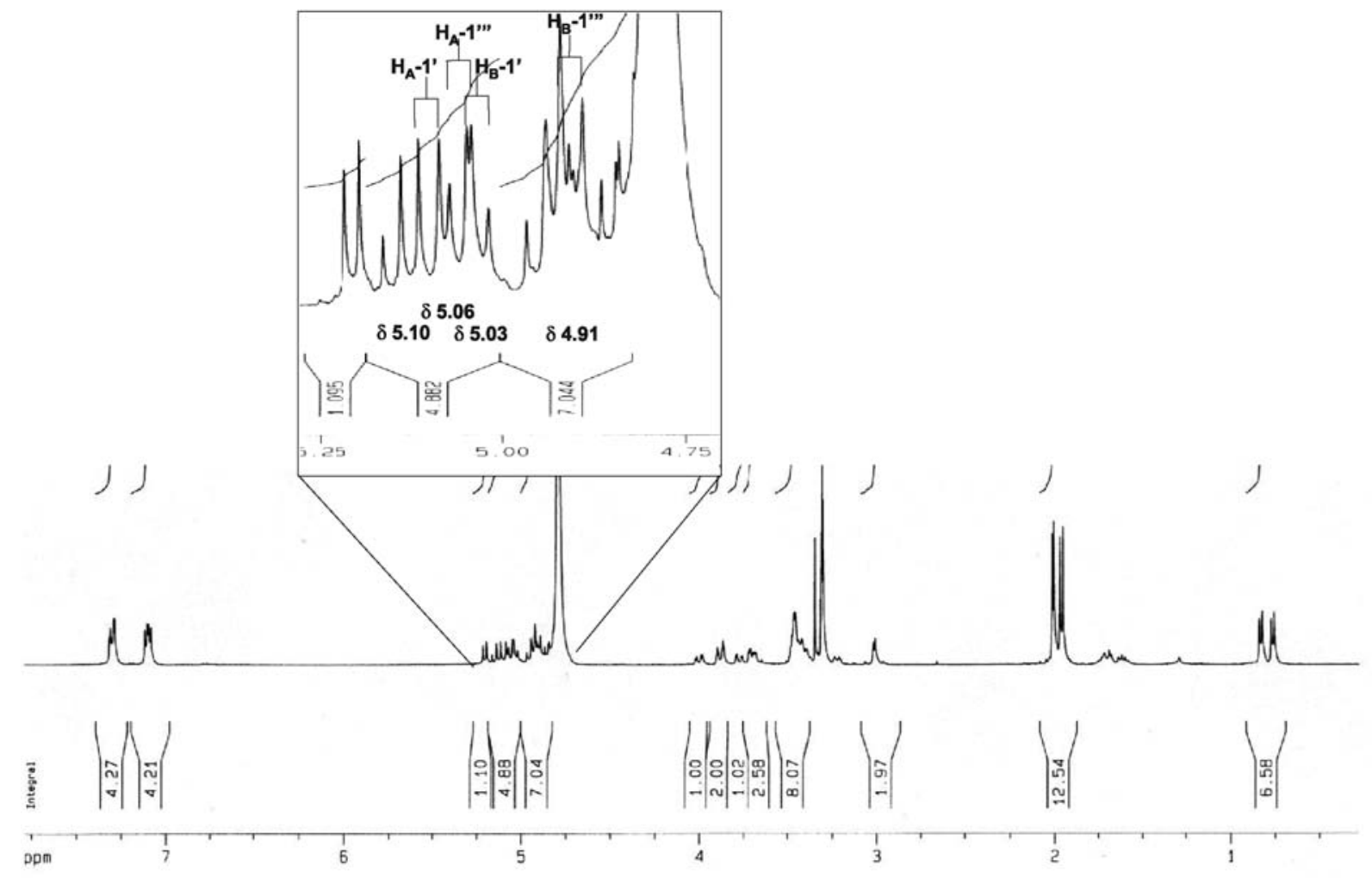

Figure S5. ${ }^{1} \mathrm{H}$ NMR spectrum of $\mathbf{4}\left(\mathrm{CD}_{3} \mathrm{OD}\right.$, ppm).

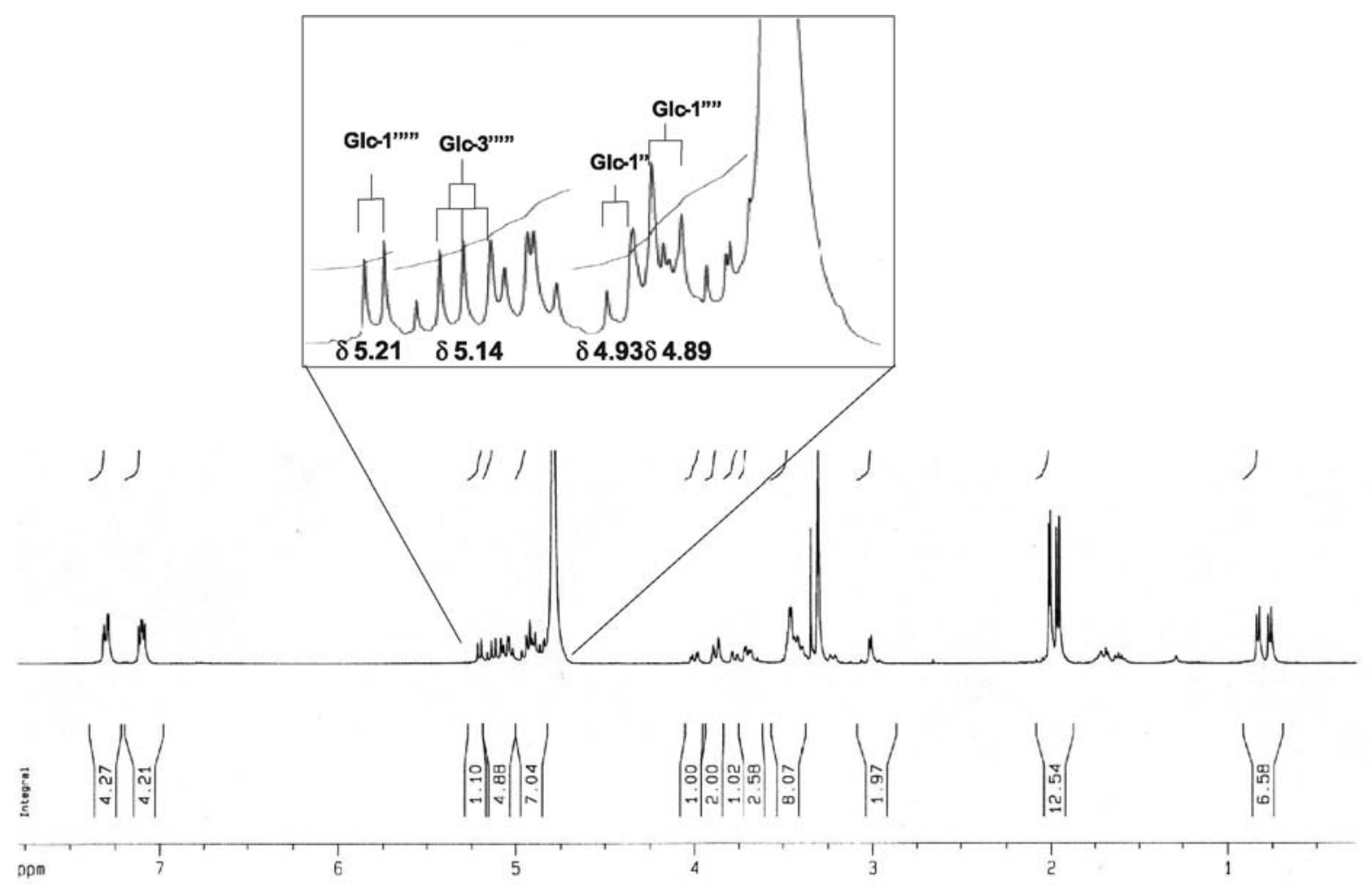

Figure S6. ${ }^{1} \mathrm{H}$ NMR spectrum of $\mathbf{4}\left(\mathrm{CD}_{3} \mathrm{OD}\right.$, ppm). 


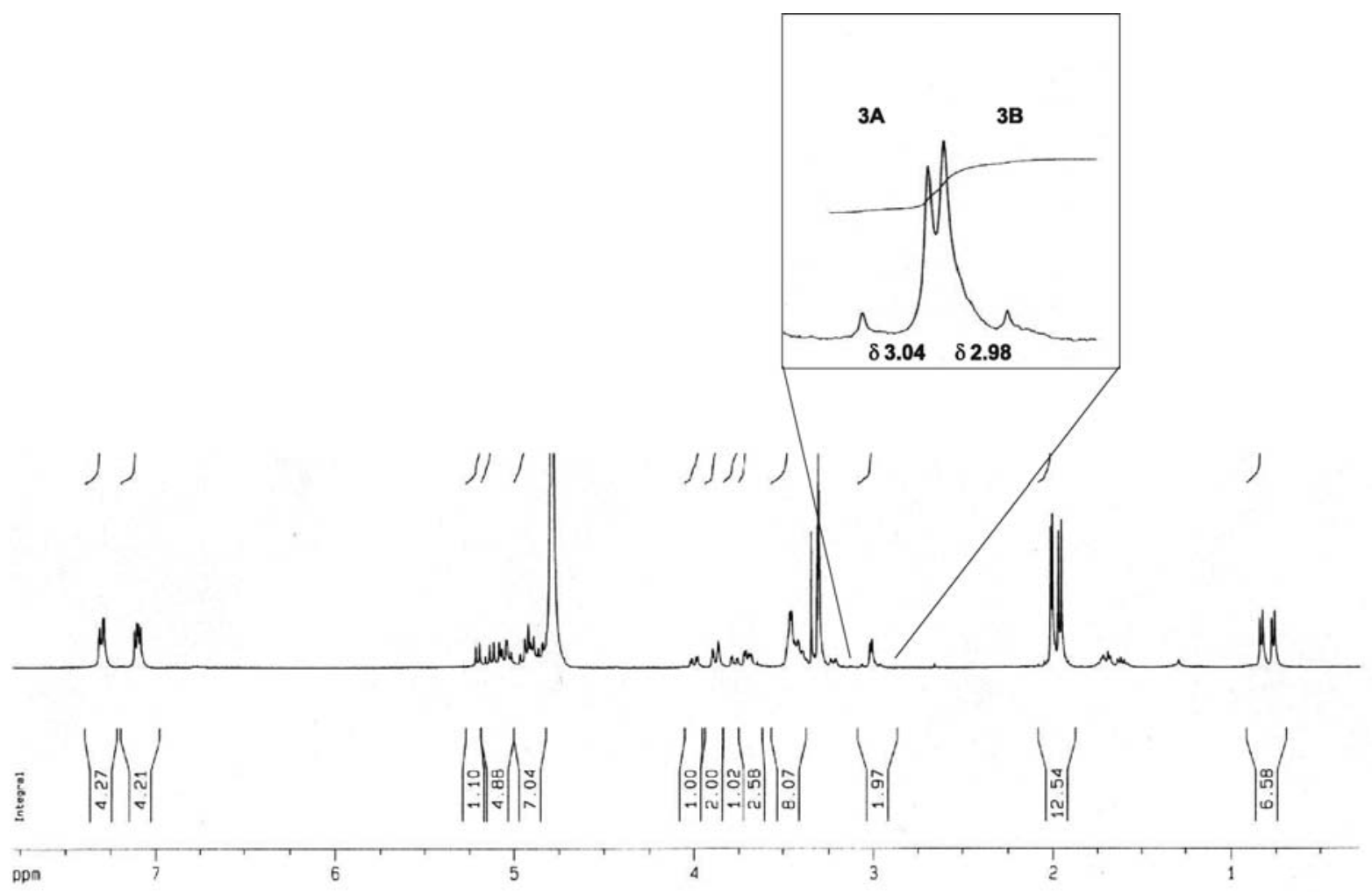

Figure S7. ${ }^{1} \mathrm{H}$ NMR spectrum of $\mathbf{4}\left(\mathrm{CD}_{3} \mathrm{OD}\right.$, ppm).

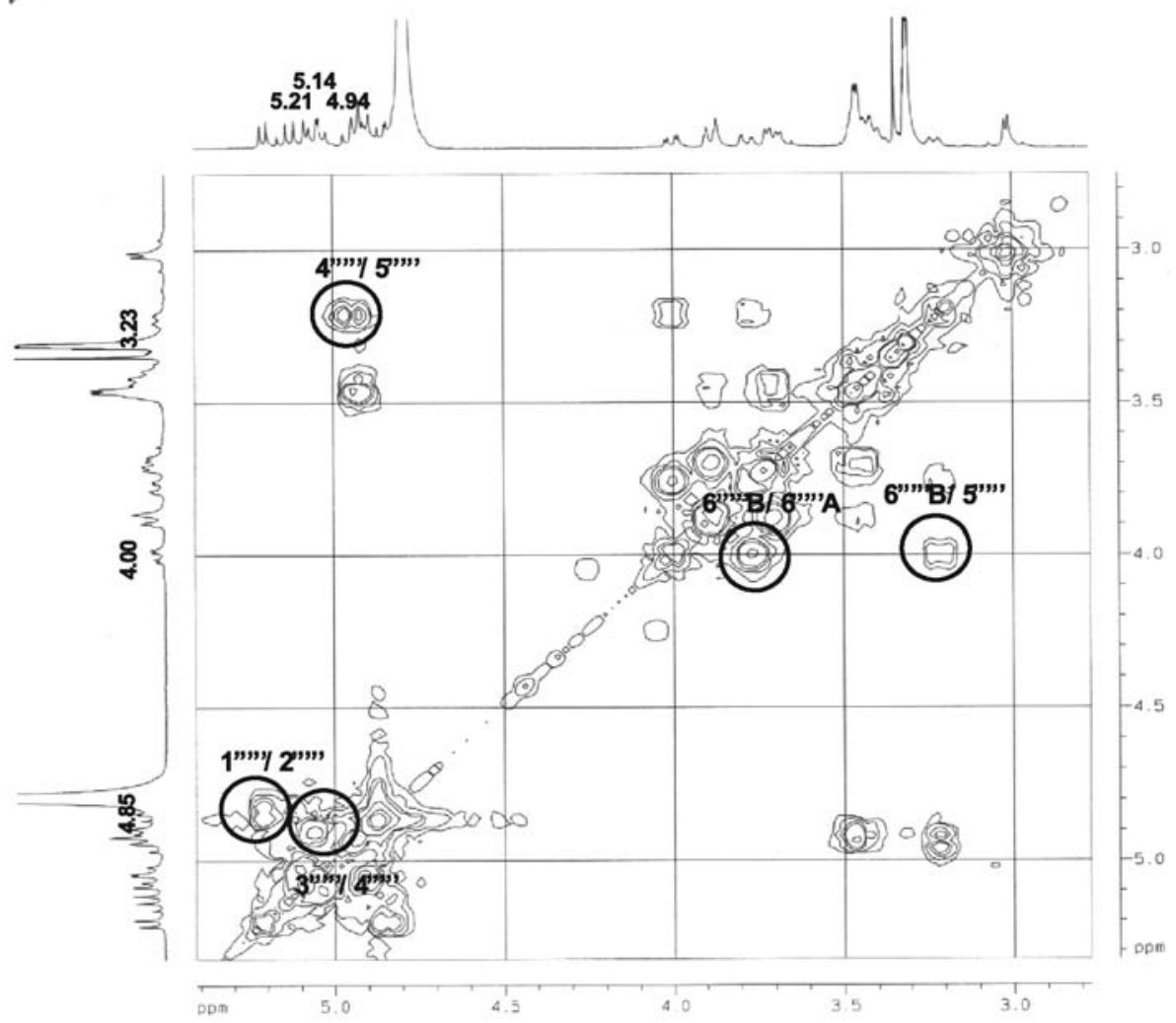

Figure S8. ${ }^{1} \mathrm{H}-{ }^{1} \mathrm{H}$ COSY NMR spectrum of $\mathbf{4}\left(\mathrm{CD}_{3} \mathrm{OD}, \mathrm{ppm}\right)$. 


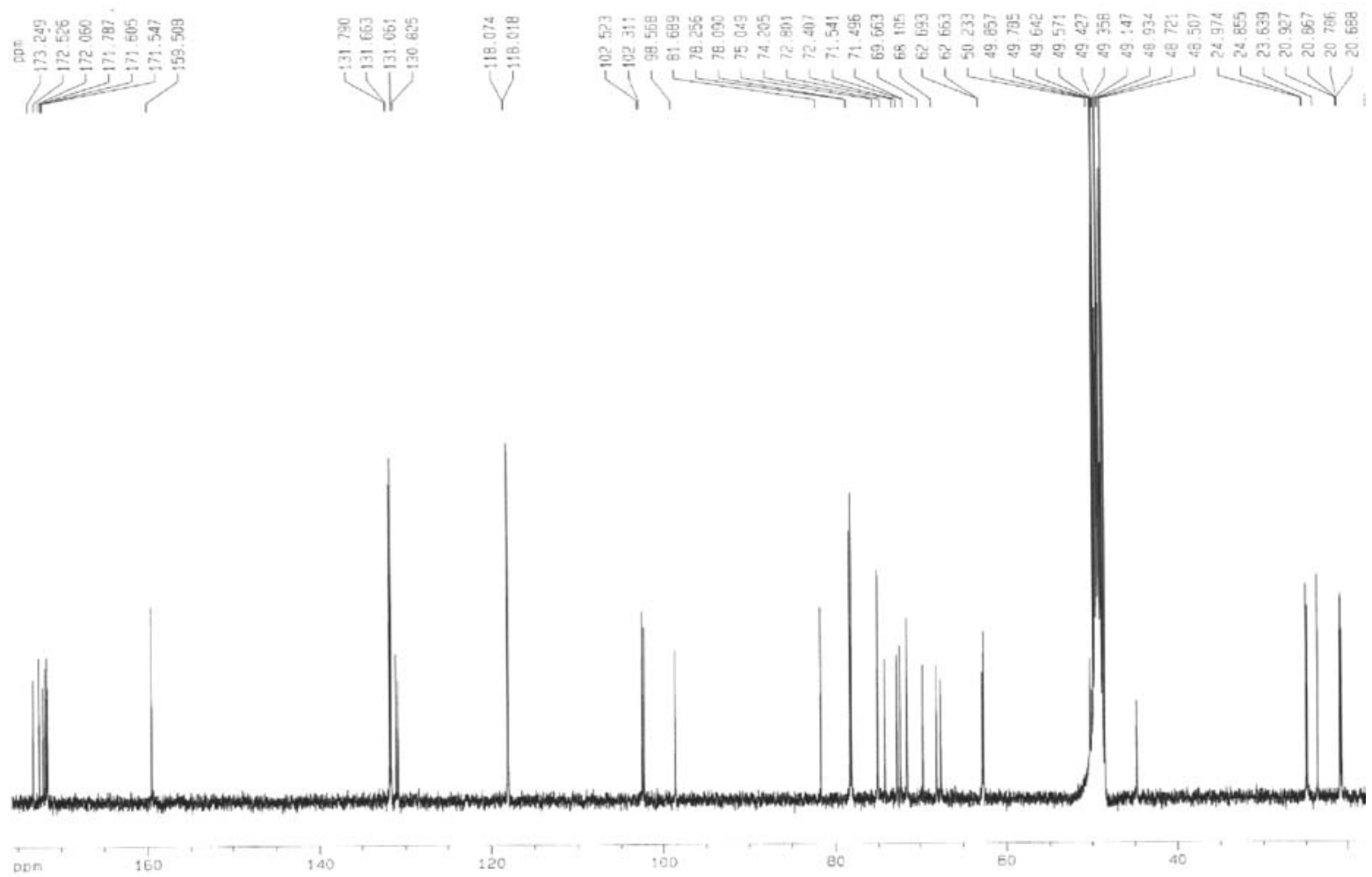

Figure S9. ${ }^{13} \mathrm{C}$ NMR spectrum of $\mathbf{4}\left(\mathrm{CD}_{3} \mathrm{OD}\right.$, ppm).

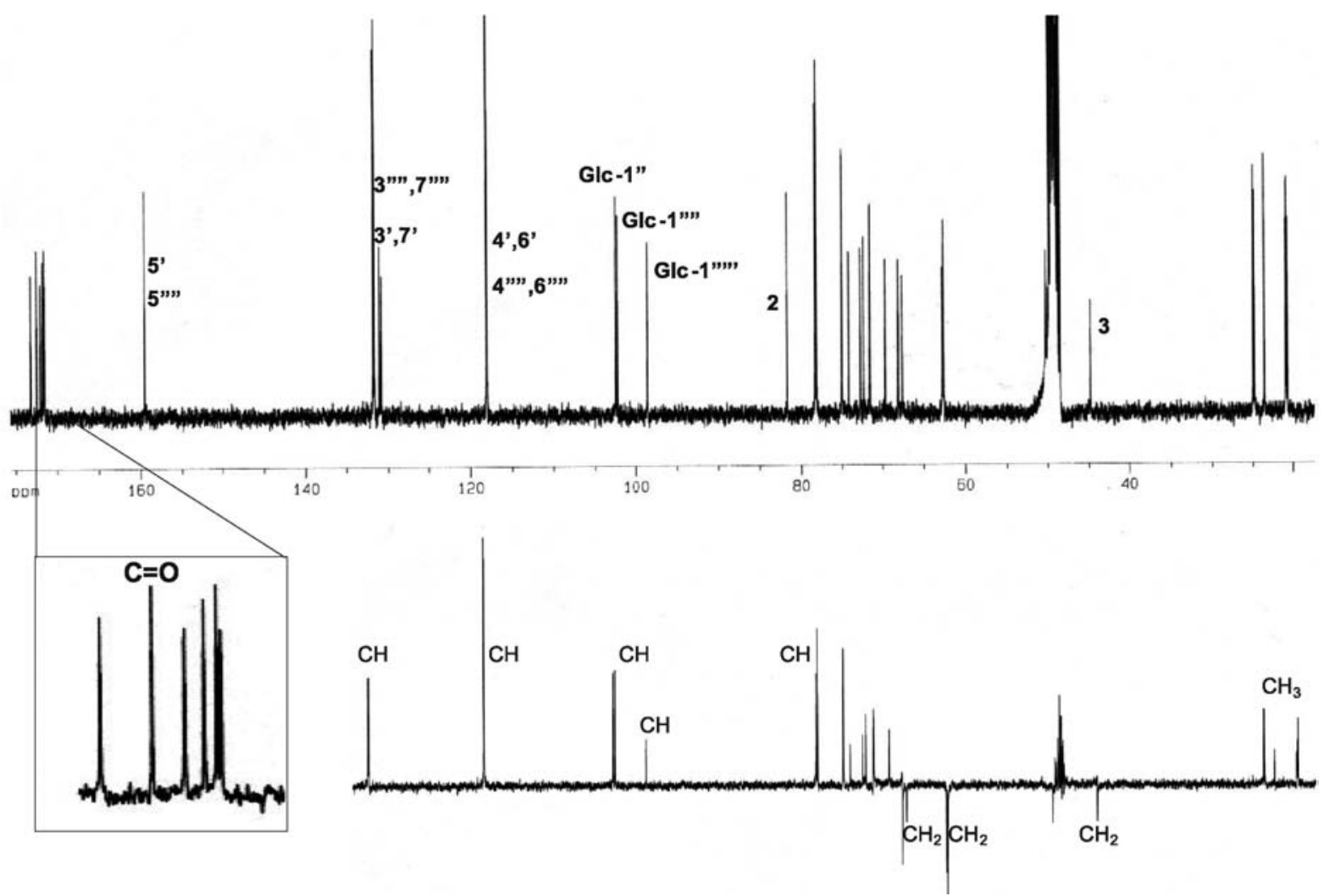

Figure S10. ${ }^{13} \mathrm{C}$ NMR spectrum of $\mathbf{4}\left(\mathrm{CD}_{3} \mathrm{OD}, \mathrm{ppm}\right)$. 


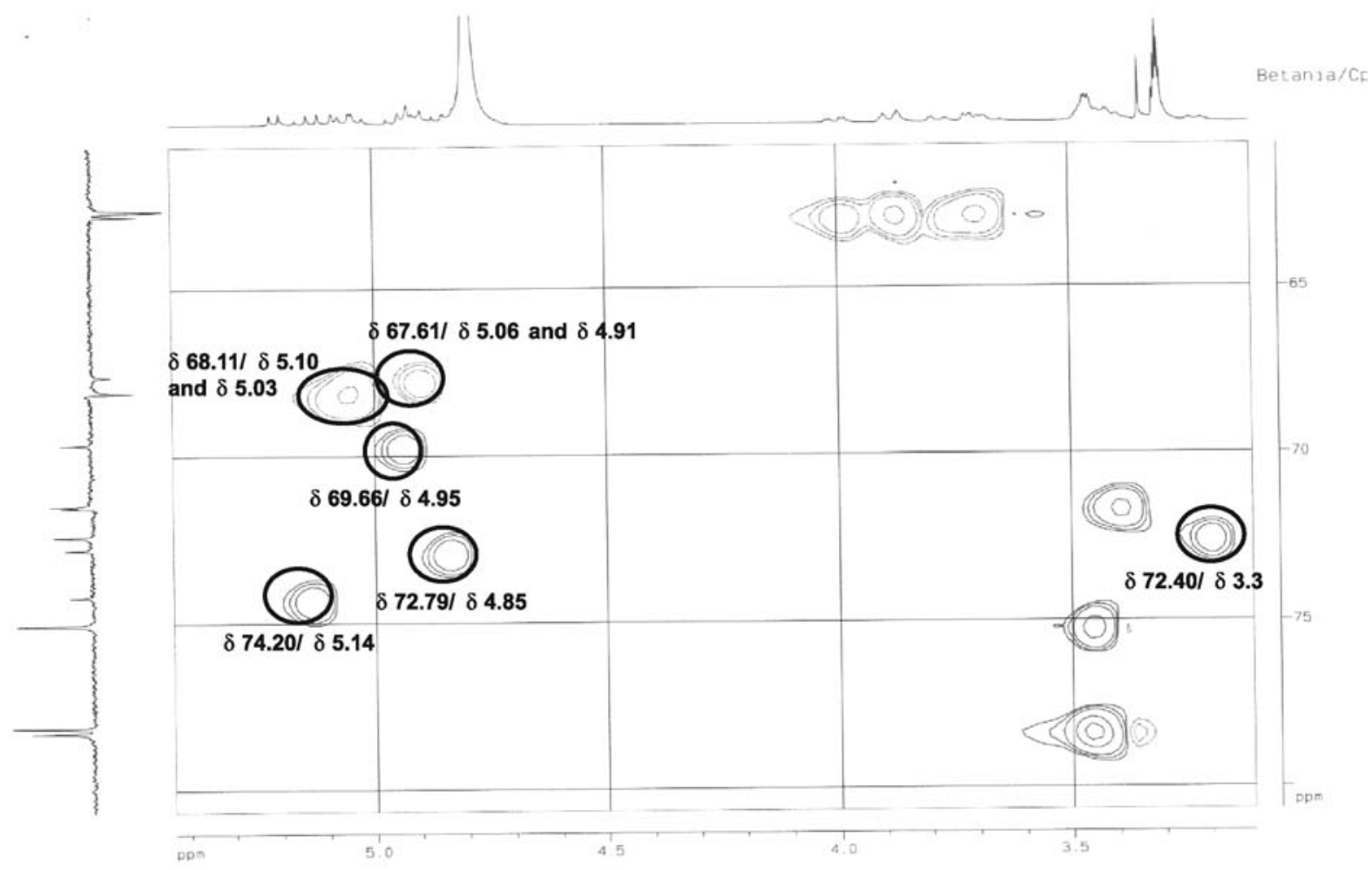

Figure S11. ${ }^{1} \mathrm{H}-{ }^{13} \mathrm{C}$ HMBC NMR spectrum of $4\left(\mathrm{CD}_{3} \mathrm{OD}\right.$, ppm).

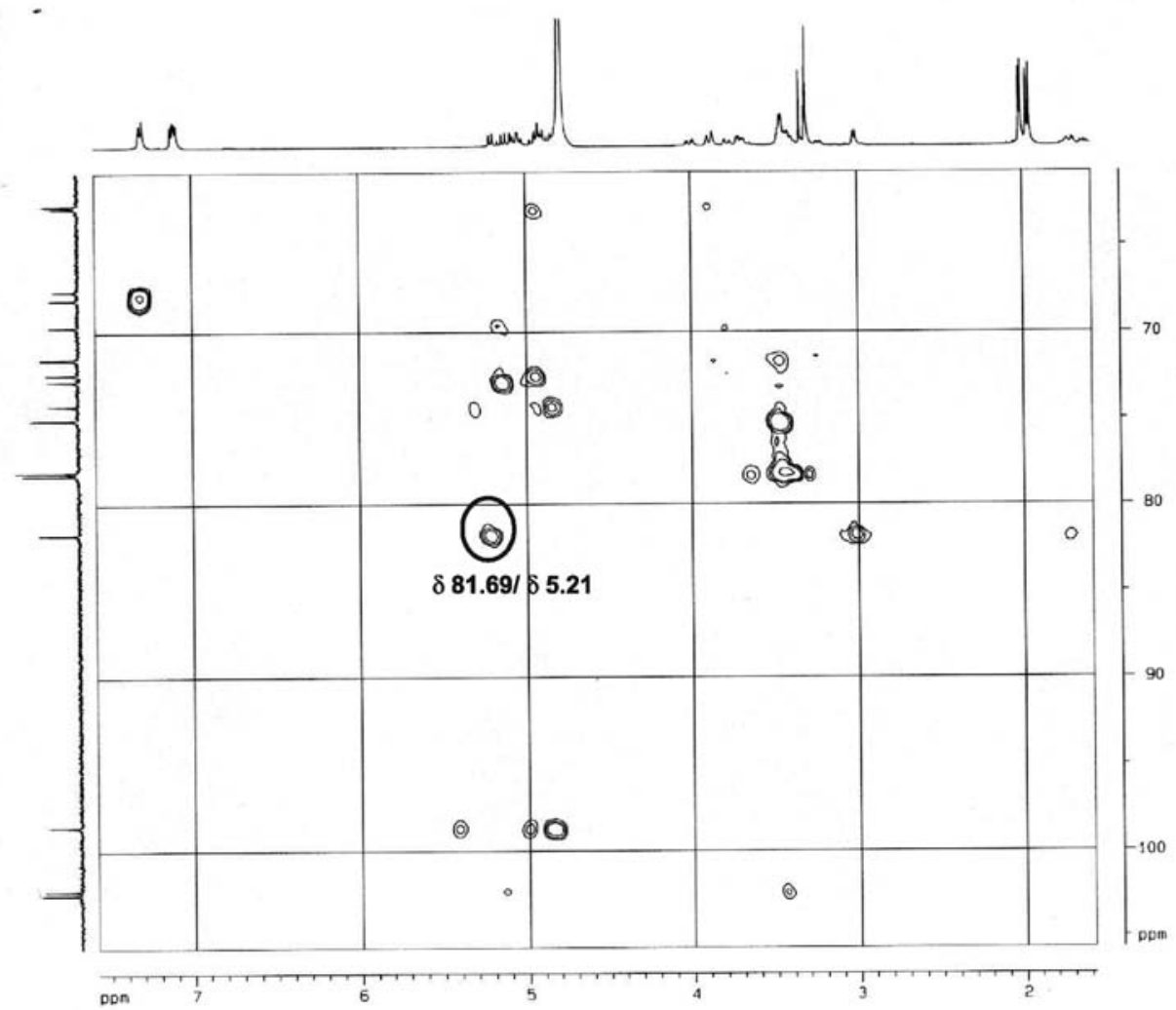

Figure S12. ${ }^{1} \mathrm{H}-{ }^{13} \mathrm{C}$ HMBC NMR spectrum of $4\left(\mathrm{CD}_{3} \mathrm{OD}, \mathrm{ppm}\right)$. 


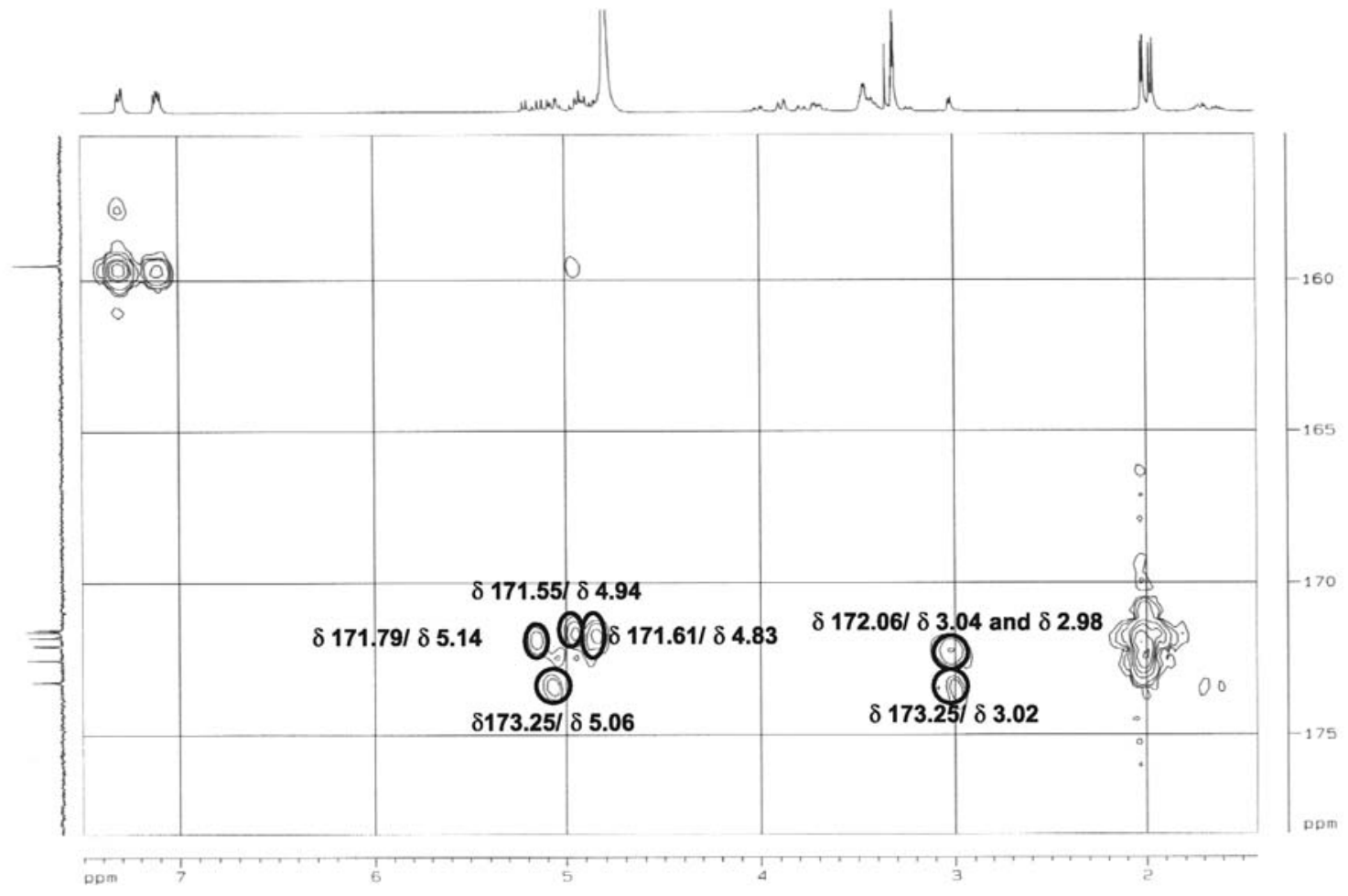

Figure S13. ${ }^{1} \mathrm{H}-{ }^{13} \mathrm{C}$ HMBC NMR spectrum of $4\left(\mathrm{CD}_{3} \mathrm{OD}, \mathrm{ppm}\right)$ 